\title{
Sporadic Pliocene and Pleistocene brachiopods in Naturalis Biodiversity Center (Leiden, the Netherlands): Records from the Mediterranean, and the North Sea Basin
}

\author{
Alfréd DulaI \\ Department of Palaeontology and Geology, Hungarian Natural History Museum, \\ H-1083 Budapest, Ludovika tér 2, Hungary.E-mail: dulai.alfred@nhmus.hu
}

\begin{abstract}
The Cenozoic Mollusc Collection of the Naturalis Biodiversity Center (NBC) contains several Pliocene and some Pleistocene brachiopods from the Mediterranean (5 Italian localities), and from the North Sea Basin (2 English localities, 1 French locality, 4 Dutch localities). The studied samples altogether yielded more than 1000, mostly fragmentary specimens ( 8 genera, 8 species). The Italian Pliocene (and Pleistocene) assemblage is dominated by large terebratulids (Terebratula ampulla), while rhynchonellids (Aphelesia bipartita) and cancellothyridids (Terebratulina retusa) are rare. The Coralline Crag samples of England are characterized by large terebratulids (Pliothyrina sowerbyana) and lingulids (Glottidia dumortieri), the zeilleriid Macandrevia cranium is rare. The only French locality yielded few brachiopods, with relatively higher diversity (P. sowerbyana is more common, the others are rare: G. dumortieri, M. cranium, Argyrotheca cf. plicata). The Dutch Pliocene samples are dominated by mostly fragmentary lingulids ( $G$. dumortieri), while the others are much less common (Notosaria nysti, P. sowerbyana, T. retusa, M. cranium). This is the first photo documentation of $N$. nysti. With 64 figures.
\end{abstract}

Key words - Brachiopoda, Mediterranean, Naturalis Biodiversity Center, North Sea, Pleistocene, Pliocene

\section{INTRODUCTION}

The studied brachiopods were found as part of the Cenozoic Mollusc Collection of the Naturalis Biodiversity Center in Leiden (the Netherlands) (see details in Dular 2013). As the result of a Synthesys visit in Naturalis (NLTAF-3270), some papers have already been published on the basis of unpublished brachiopod materials separated from the Cenozoic Mollusc Collection. A small fauna from the Upper Miocene layers of Tetti Borelli (Piemonte, North Italy) yielded 6 species (Dular 2010). (On the basis of the NBC collection labels, the Tetti Borelli fauna was erroneously indicated as Messinian in age. However, according to JANSSEN (2012) the pteropod fauna of this locality refers to the Tortonian). Description of a new Central Paratethyan Argyrotheca spe- 
cies was partly also based on material from NBC (Dulai \& STACHACZ 2011). Geochemical analysis of Miocene and Pliocene phosphatic shelled brachiopods (lingulids, discinids) yielded important results on palaeoenvironments and ancient connections among different seas (Kocsis et al. 2012). Sporadic Miocene brachiopods from different palaeogeographic realms (Mediterranean, North Sea, and Atlantic Ocean, respectively) were presented by DulaI (2013) (12 species from 16 localities). Central Paratethyan Middle Miocene (Badenian) brachiopods are also represented in the NBC collection (DULAI 2015). A voluminous paper on Maltese Oligocene and Miocene brachiopods is partly based on materials stored in Naturalis (DULAI et al. in prep.). Some other papers are also in preparation ("Redonian" brachiopods from France, Miocene and Pliocene brachiopods from Belgium, Neogene Discinidae brachiopods from the North Sea Basin). The present part of this series deals with some sporadic Pliocene brachiopod materials from the Mediterranean and the North Sea Basin. Samples of a Mediterranean locality contain few Pleistocene specimens, which were also included in this study.

There were four marine provinces in Europe during the Miocene: the Atlantic Ocean, the North Sea, the Paratethys and the Mediterranean. For the Late Miocene and the Pliocene marine conditions ceased in the Central Paratethys. Last widespread normal marine assemblages, including brachiopods were identified from the Middle Miocene Badenian (Langhian-Early Serravallian) (see references in Bitner 1990; Bitner \& Dulai 2004; Dulai 2015). The subsequent Sarmatian (= Late Serravallian) was characterized mainly by brackish environments, without stenohaline organisms (e.g. without brachiopods). However, some authors supposed partly normal marine conditions in the Sarmatian, too (e.g. Piller \& Harzhauser 2005). Recently, few brachiopods were reported from the Sarmatian of Sandberg, Vienna Basin (BITNER et al. 2014), however, redeposition from the Badenian cannot be excluded unambiguously. For the Late Miocene and Pliocene Lake Pannon occupied the Carpathian Basin with lacustrine environments. However, the other marine realms continued from Miocene to Pliocene, and brachiopods were recorded from all three areas in the literature. The studied sporadic samples of the Naturalis Biodiversity Center yielded Pliocene brachiopods from the Mediterranean and the North Sea Basin.

\section{PLIOCENE BRACHIOPODS IN EUROPE - PREVIOUS RESEARCH}

Mediterranean - Pliocene brachiopods of the Mediterranean were published mainly from Spain and Italy. After some historical records, PAJAuD (1976) mentioned Terebratula terebratula, and described Phapsirhynchia sancta- 
paulensis as new genus and species from the Lower Pliocene glauconitic and biodetritic facies of Alicante region. PAJAud (1977) described eight species from the Lower Pliocene organodetritic facies of Águilas. MARTINELL (1982) recorded borings produced by Pliocene brachiopods in Catalonia. Encinas \& Martinell (1992) found five species in the Pliocene of Empordà Basin (Catalonia). Calzada (1997) mentioned Megerlia eusticta from Almeria. Bitner \& Martinell (2001) described four species from the Lower Pliocene sandy deposits of Estepona. (It is worth mentioning that a new private collection from Estepona yielded 12-13 species; DULAI \& MUlder in prep.). GaRCIA Ramos (2004) mentioned 11 brachiopod species from Águilas and later five species from the Lower Pliocene of SE-Spain (GARCIA RAMOs 2005). The above author (GARCIA Ramos 2006) summarized the European Tertiary terebratulids, including some Pliocene forms, too. TosCANO-GRANDE et al. (2010) described three species from the Guadalquivir Basin, and summarized 11 species from the Pliocene of Spain.

DAVIDSON (1870) and SACCO (1902) described the Tertiary brachiopods of Italy including some Pliocene species, too. Foresti (1893) documented 10 species in the Pliocene sediments of Bologna. Gaetani \& SAccÀ (1984) discussed bathyal brachiopods from the Pliocene and Pleistocene of Sicily and Calabria. GaEtani \& SACCÀ (1985a) described 12 species from nine Late Pliocene localities of Messina and Calabria. GAETANi \& SACCÀ (1985b) revised the genus Aphelesia. SACCÀ (1986) mentioned Megerlia echinata from Sicily and Calabria. Gaetani (1986) discussed Pliocene and Pleistocene palaeocommunities from Sicily and Calabria, and distinguished three main facies groups from the Pliocene. BENIGNi \& RoBBA (1990) discussed a micromorphic brachiopod-pectinid assemblage from the Late Zanclean sands (with four brachiopod species). TADDEI Ruggiero $(1994,1996)$ mentioned brachiopods from the Salento Neogene and the Gravina calcarenite. Borghi (2001) described 10 species from Emilia. LEE et al. (2001) revised the type species $T$. terebratula and confirmed the presence of T. ampulla in the Pliocene of Emilia and Toscana. Bertolaso et al. (2009) described 11 Pliocene species from Emilia.

From other parts of the Mediterranean Pliocene brachiopods are not so well-known. Dermitzakis (1969) mentioned seven species from different Pliocene localities of Crete. Six species were recorded from Upper Pliocene sandy and calcareous deposits of the Rhodes Island by Kos KERIDOU (2007). From the southern, African part of the Mediterranean Dautzenberg (1909) described a new rhynchonellid species from the Pliocene of Algeria. Seven Pliocene species were described from Algeria and Morocco by Bitner \& Moissette (2003), while the high frequency of predatory drill holes in Pliocene brachiopod shells was recorded by BAUMILLER et al. (2006). 
North Sea Basin - ChARLeSworth (1837) described a "gigantic" species of Terebratula from the Coralline Crag of England ( $T$. maxima). DAvidson $(1852,1874 a)$ described the Tertiary brachiopod fauna of Great Britain, including some Pliocene forms, too. The brachiopods of the Pliocene Coralline Crag in England were studied in detail by WooD (1872). BUCKMAN (1908) discussed the nomenclatural problems of large terebratulids from the Coralline Crag. BELL (1921) described a new species, Terebratula harmeri, which later was also accepted by Muir-Wood (1938) who separated two species (T. maxima, T. orfordensis) from the Coralline Crag, and three species (T. harmeri, T. perforata, T. variabilis) from the Red Crag of the British Pliocene. Cooper (1983) erected a new genus (Apletosia) for the Pliocene species maxima. HARPER (2005) studied the predation damages on Coralline Crag Apletosia maxima. Apletosia was synonymized with Pliothyrina in the revised new Treatise (LEE \& SMIRnOva 2006).

Nyst (1843) described two important and wide-spread species, Lingula dumortieri and Terebratula sowerbyana from the Pliocene of Belgium. DAvidson (1874b) and VinCENT (1893) described the Tertiary brachiopods of Belgium, including some Pliocene forms, too. Dautzenberg \& Dolfuss (1896) studied large Pliocene terebratulids around Anvers. VAN Roy (1980) described a new genus, Pliothyrina for large terebratulids of the Neogene of Belgium. LACOURT (1983) mentioned 30 different species names for large terebratulids of the Netherlands, including some new species. WESSELINGH (2003) mentioned Terebratula grandis (actually, Pliothyrina sowerbyana) from Westerschelde. RAAD (2004a, b, 2008) discussed Pliothyrina from the Netherlands. VAN NiEulande (2009) described in more details the "strand fossils" of the Netherlands and mentioned the difference between Pliothyrina sowerbyana and Terebratula sp. Vos Kuil (2004) discussed in detail not only the large terebratulids, but all brachiopods known from the strand fossils of the Netherlands, and he revised correctly LACOURT's (1983) unestablished work. WESSELINGH et al. (2013) described a lingulid (Glottidia)-dominated assemblage from the Late Pliocene of the eastern Netherlands. MoERDIJK (2016) discussed the nomenclatural problems of Miocene and Pliocene Pliothyrina assemblages of the North Sea Basin.

\section{MATERIAL}

All studied specimens were found in the Cenozoic Mollusc Collection of NBC. Locality data are mainly according to the NBC labels of specimens and personal information by Ronald Pouwer (NBC collection manager). The studied specimens are under the inventory numbers prefixed by RGM (Rijksmuseum van 
Geologie en Mineralogie). Only some important references are given on the general aspects and previous brachiopod records of the localities.

\section{Mediterranean}

Italy

(Fig. 1)

Asti, Valle Andona (Piemonte region, Asti province), $200 \mathrm{~m} \mathrm{~N}$ of the village, right side of the road. Pliocene, Piacenzian (= "Astian"), collected by H. J. W. G. Schalke and M. van den Bosch, 1969. The type locality of the regional stage "Astian" is in the Valle Andona, about $6 \mathrm{~km}$ west of Asti (calcareous sands, shell conglomerates, oyster beds, soft marls; BERGGREN \& VAN CoUverING 1974).

Terebratula ampulla (Brocchi, 1814), 3 pedicle valves, RGM.115498; 1 complete specimen (Figs 19-21), RGM.1309882; 1 pedicle valve (Fig. 26), RGM.1309883

Lugagnano (Emilia-Romagna region, Piacenza province), Monte Giogo outcrop. Pliocene, Piacenzian, collected by H. J. W. G. Schalke and M. van den Bosch, May-August 1969 (NBC internal Report 21, 1970). Geology and palaeontology of Monte Giogo and its surroundings, including Castell'Arquato and Stirone River was discussed by Monegatti et al. (2001).

Terebratula ampulla (Brocchi, 1814), 3 fragmentary pedicle valves, RGM.1309884

Lugagnano, unspecified locality, probably Pliocene.

Terebratula ampulla (Brocchi, 1814), 1 pedicle valve (Figs 24-25), RGM.1309885

San Nicomede (Emilia-Romagna region, Parma province), Streambed Torrente Stirone, Pleistocene, Gelasian, grey sandy clay, collected by A. W. Janssen, 21 June 1988. According to JANSSEN (2012) the pteropod assemblage of the same samples refer to Pleistocene (Gelasian) age (Pteropod Zone 24). Some brachiopods were mentioned from this locality by BORGHI (2001).

About 4.7-8.2 m below the base of sandstone level:

Terebratula ampulla (Brocchi, 1814), 1 brachial valve, RGM.1309891; 1 brachial valve (Figs 33-34), RGM.1309892

About 8.2-8.6 $\mathrm{m}$ below the base of sandstone level:

Terebratula ampulla (Brocchi, 1814), 6 pedicle valves, RGM.1309886; 4 brachial valves, RGM.1309887; 1 brachial valve (Figs 27-29), RGM.1309888; 1 pedicle valve (Figs 30-31), RGM.1309889; 1 brachial valve (Fig. 32), RGM.1309890

Ceriale (Liguria region, Savona province), outcrop in streambed of Rio Torsero. Pliocene, Piacenzian, grey clays, collected by A. W. Janssen, July 1988. Pteropods of this locality indicate Pteropod Zone 22 (JAnssen 2012). The very 
diverse mollusc fauna was described by ANDRI et al. (2005), while some brachiopods were mentioned by SACCO (1902).

Aphelesia bipartita (Brocchi, 1814), 1 complete specimen, 1 brachial valve, RGM.1309893; 1 complete specimen (Figs 10-12), RGM.1309894; 1 pedicle valve (Fig. 13), RGM.1309895

Terebratula ampulla (Brocchi, 1814), 2 complete specimens, 9 pedicle valves, 2 fragments, RGM.1309896; 1 complete specimen (Figs 22-23), RGM.1309897; 8 brachial valves, RGM.1309898; 1 brachial valve, RGM.1309899

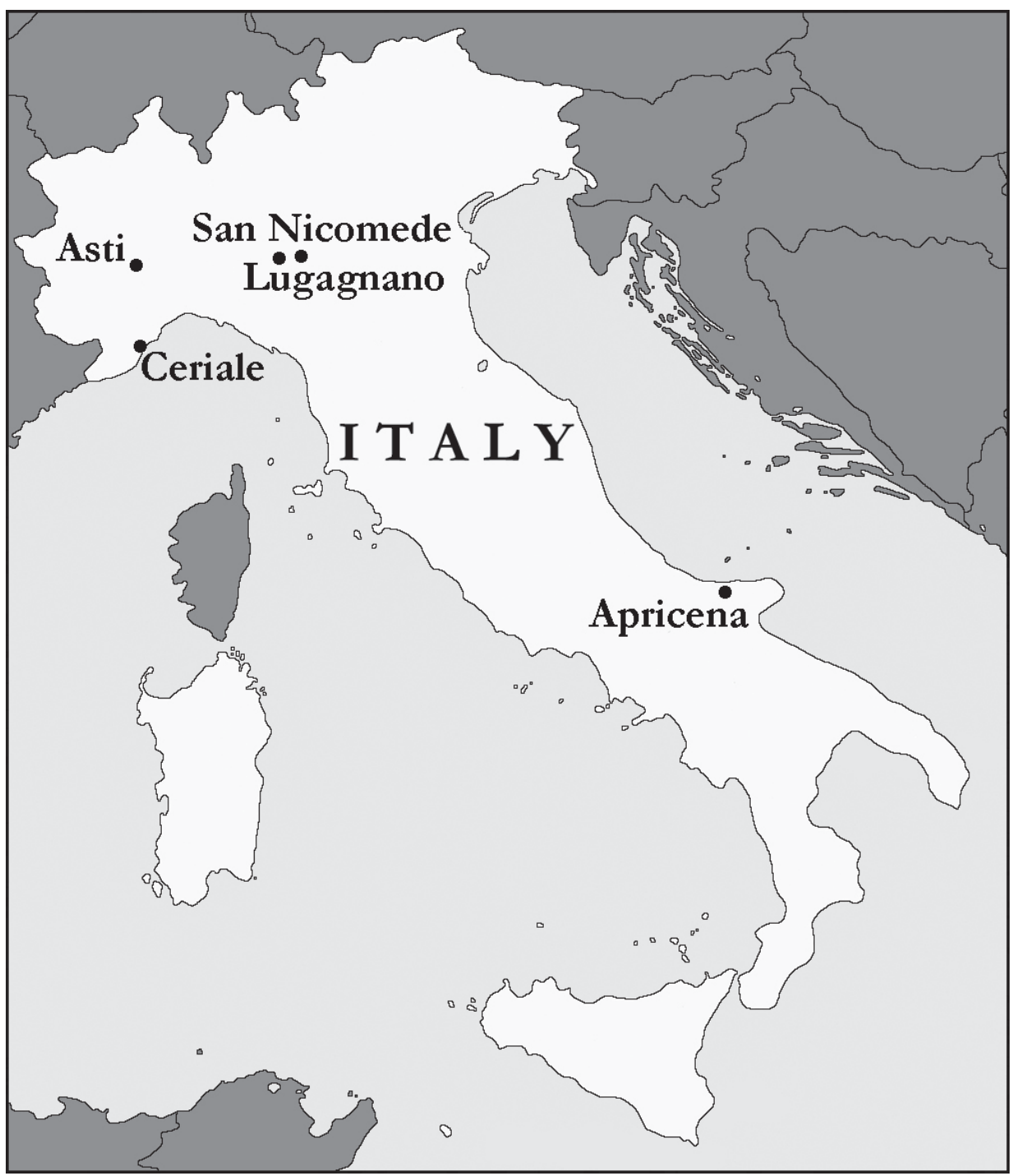

Fig. 1. Location of the studied Italian Pliocene (and Pleistocene) localities 
Apricena (Puglia region, Foggia province), Pirro limestone quarry, Pliocene. Neogene stratigraphy and sedimentology of the Gargano Promontory was given by CASOLARI et al. (2000) and shallow-water deposits (Gravina Calcarenites) were mentioned from the Middle-Late Pliocene. PAVia et al. (2010) studied the tectonosedimentary evolution of western Gargano and mentioned some brachiopods, too.

Terebratula ampulla (Brocchi, 1814), 2 fragmentary pedicle valves and 1 brachial valve, RGM.1309900

Terebratulina retusa (Linnaeus, 1758), 1 complete specimen, RGM.1309901

\author{
North Sea Basin \\ England \\ (Fig. 2)
}

Gedgrave (Suffolk), Butley River cliff outcrop, $52.084167 \mathrm{~N} ; 1.497500 \mathrm{E}$. Pliocene, Zanclean, Coralline Crag Formation, collected by A. W. Janssen, 14 September 1987. Lithostratigraphy of the Coralline Crag was given by BALSON et al. (1993) on the basis of seven boreholes between Gedgrave and Aldeburgh. Brachiopods of the Coralline Crag were discussed by classical papers as WooD (1872) and DAvidson (1874a).

0.55-0.85 m below top of Pliocene deposits:

Glottidia cf. dumortieri (Nyst, 1843), 80 fragments, RGM.793905; fragmentary valve (Figs 8-9), RGM.793904; fragmentary valve (Figs 5-6), RGM.1309902

Pliothyrina sowerbyana (Nyst, 1843), 8 pedicle and 9 brachial valves, RGM.793906; 1 complete specimen (Figs 38-40) and 1 pedicle valve, RGM.793903

Macandrevia cranium (Müller, 1776), 1 pedicle valve, RGM.1309903; 1 complete specimen (Figs 56-57), RGM.1309904; 1 pedicle valve (Fig. 59), RGM.1309905

0.85-1.00 m below top of Pliocene deposits:

Glottidia? sp., 24 fragments, RGM.793911

Pliothyrina sowerbyana (Nyst, 1843), 1 pedicle valve (Figs 43-45), RGM.793907; 1 complete specimen (Figs 35-37), RGM.793908; 4 pedicle and 13 brachial valves, RGM.793909

Pliothyrina sp., 8 fragments, RGM.793910

1.00-1.25 m below top of Pliocene deposits:

Glottidia cf. dumortieri (Nyst, 1843), 39 fragments, RGM.793912

Pliothyrina sowerbyana (Nyst, 1843), 5 brachial valves, 7 pedicle valves, RGM.793913

Pliothyrina sp., 14 indeterminable fragments, RGM.793914

Macandrevia cranium (Müller, 1776), 1 pedicle valve (Fig. 60), RGM.1309917; 1 brachial valve, RGM.1309918

1.25-1.45 m below top of Pliocene deposits:

Glottidia cf. dumortieri (Nyst, 1843), 15 fragments, RGM.793917

Pliothyrina sowerbyana (Nyst, 1843), 4 pedicle valves, 5 brachial valves, RGM.793915

Pliothyrina sp., 33 fragments, RGM.793916 
1.50-1.70 m below top of Pliocene deposits:

Glottidia cf. dumortieri (Nyst, 1843), 4 fragments, RGM.793920

Pliothyrina sowerbyana (Nyst, 1843), 2 pedicle and 3 brachial valves, RGM.793918

Pliothyrina sp., 21 fragments, RGM.793919

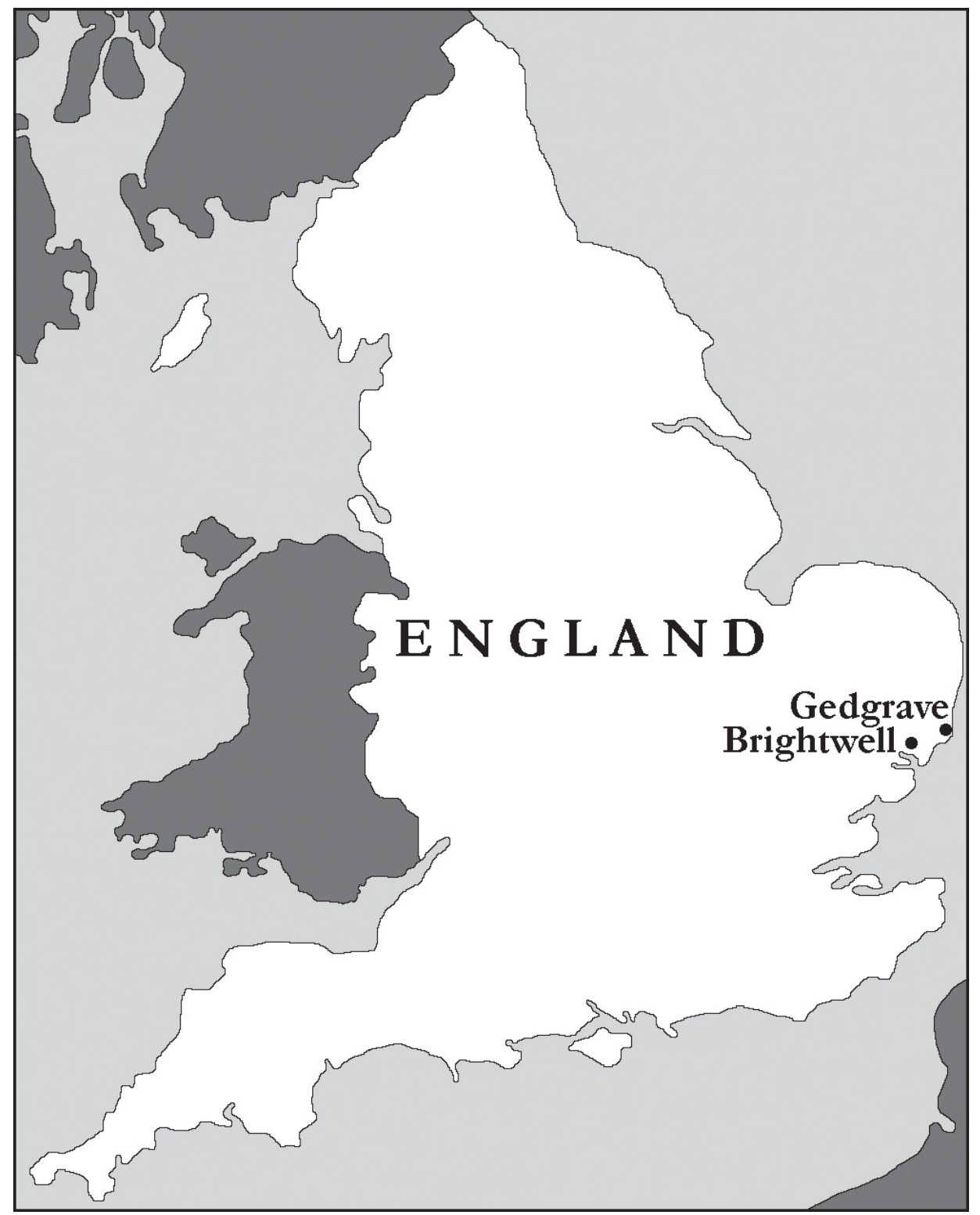

Fig. 2. Location of the studied British Pliocene localities 
1.70-1.90 m below top of Pliocene deposits:

Glottidia cf. dumortieri (Nyst, 1843), 19 fragments, RGM.793925

Pliothyrina sowerbyana (Nyst, 1843), 22 pedicle valves, RGM.793922; 14 brachial valves, RGM.793923; 1 brachial valve (Figs 41-42), RGM.793921

Pliothyrina sp., 100 fragments, RGM.793924

Macandrevia cranium (Müller, 1776), 1 complete specimen (Fig. 55), RGM.1309906

Brightwell (Suffolk), Brightwell Hill, abandoned sandpit, $52.039167 \mathrm{~N}$, 1.280000 E. Pliocene, Piacenzian, Red Crag Formation ("Newbournian Red Crag"), collected by A. W. Janssen, 1 April 1970. Stratigraphy and palaeoenvironments of the Red Crag was discussed in detail by ZALASIEwICZ et al. (1988).

Pliothyrina sowerbyana (Nyst, 1843), 1 brachial valve, RGM.793926

\section{France}

(Fig. 3)

Cricqueville-en-Bessin (Basse-Normandy, Calvados), temporary excavation in meadow, Pliocene, yellowish sands with shells, collected by A. W. Janssen, September 1988. The fossiliferous locality of Cricqueville-en-Bessin was studied in detail by PAREYN et al. (1983).

Glottidia cf. dumortieri (Nyst, 1843), 1 fragment (Fig. 7), RGM.1309907; 1 fragment, RGM.1309908

Pliothyrina sowerbyana (Nyst, 1843), 1 brachial valve (Fig. 46), RGM.1309909; 4 brachial valves, RGM.1309910; 5 pedicle valves, RGM.1309911; 1 pedicle valve, RGM.1309912; 1 complete juvenile specimen, RGM.1309913

Macandrevia cranium (Müller, 1776), 1 pedicle valve (Fig. 58), RGM.1309914; 1 pedicle valve, RGM.1309915

Argyrotheca cf. plicata (de Morgan, 1915), 1 pedicle valve (Figs 61-64)

Terebratulida indet., 4 fragments, RGM.1309916

\section{The Netherlands}

(Fig. 4)

Goes (Zeeland), unspecified borehole (Pouwer, pers. comm.).

$68 \mathrm{~m}$ below surface, Pliocene:

Terebratulida indet sp. (not Terebratella cf. spitzbergensis as indicated on the label), 4 indeterminable fragments, RGM.29657

Terebratulida indet sp. (not Terebratulina caputserpentis as indicated on the label), 1 indeterminable fragment, RGM.29672

Pliothyrina? indet. sp. (not Argiope cf. cistellula as indicated on the label), 1 fragment, RGM.29679

$74 \mathrm{~m}$ below surface, Pliocene: 
Pliothyrina cf. sowerbyana (Nyst, 1843) (not Terebratula maxima as indicated on the label), 3 large fragments, RGM.29658

Pliothyrina sowerbyana (Nyst, 1843), 2 pedicle valves and 1 brachial valve (Figs 47-48), RGM.14604

$87 \mathrm{~m}$ below surface, Pliocene:

Pliothyrina cf. sowerbyana (Nyst, 1843) (not Terebratula maxima as indicated on the label), 3 fragmentary specimens, RGM.29678

$101 \mathrm{~m}$ below surface, Early Pliocene or Miocene:

Terebratulida indet. sp. (not Terebratula grandis as indicated on the label), 4 indeterminable fragments, RGM.29671

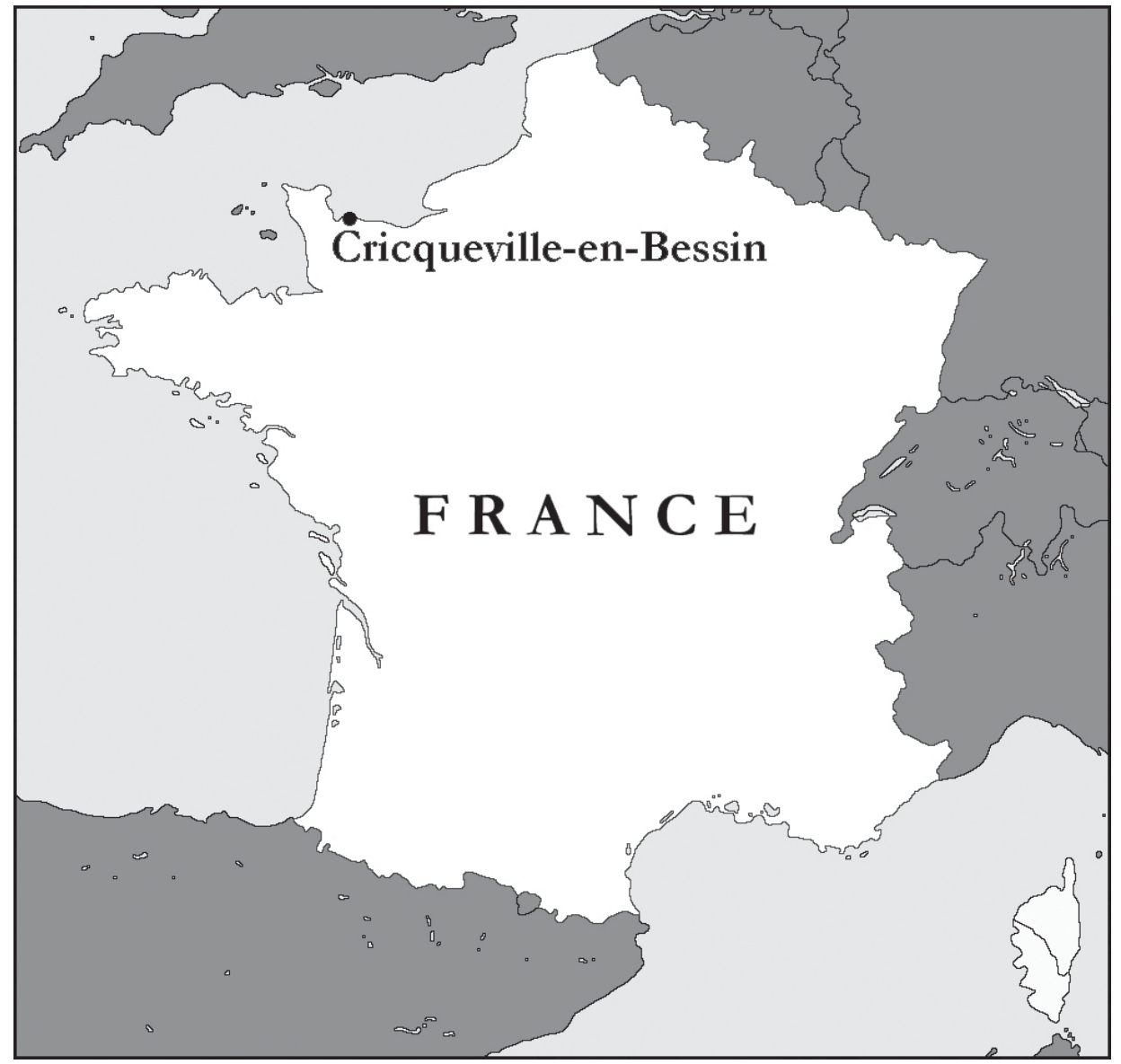

Fig. 3. Location of the studied French Pliocene locality 
Kreekrak (Zeeland), Kreekraksluizen, borehole 49D.12-15, 51.40995 N, 4.21999 E. Pliocene, Zanclean, Breda Formation (Kattendijk Sands equivalent), Petaloconchus Bed, collected and donated by Rijkswaterstaat. Deltadienst, 1968 47-50 m below surface:

Notosaria nysti (Davidson, 1874) 1 complete specimen (Figs 14-15), RGM.1309924; 1 brachial valve (Figs 16-17), RGM.1309925; 1 brachial valve (Fig. 18), RGM.1309926

Terebratulina retusa (Linnaeus, 1758), 1 fragmentary brachial valve, RGM.1309919

Macandrevia cranium (Müller, 1776), 1-1 fragmentary brachial and pedicle valve, RGM.1309920

$50-51 \mathrm{~m}$ below surface:

Glottidia? sp., 7 fragments, RGM.1309921

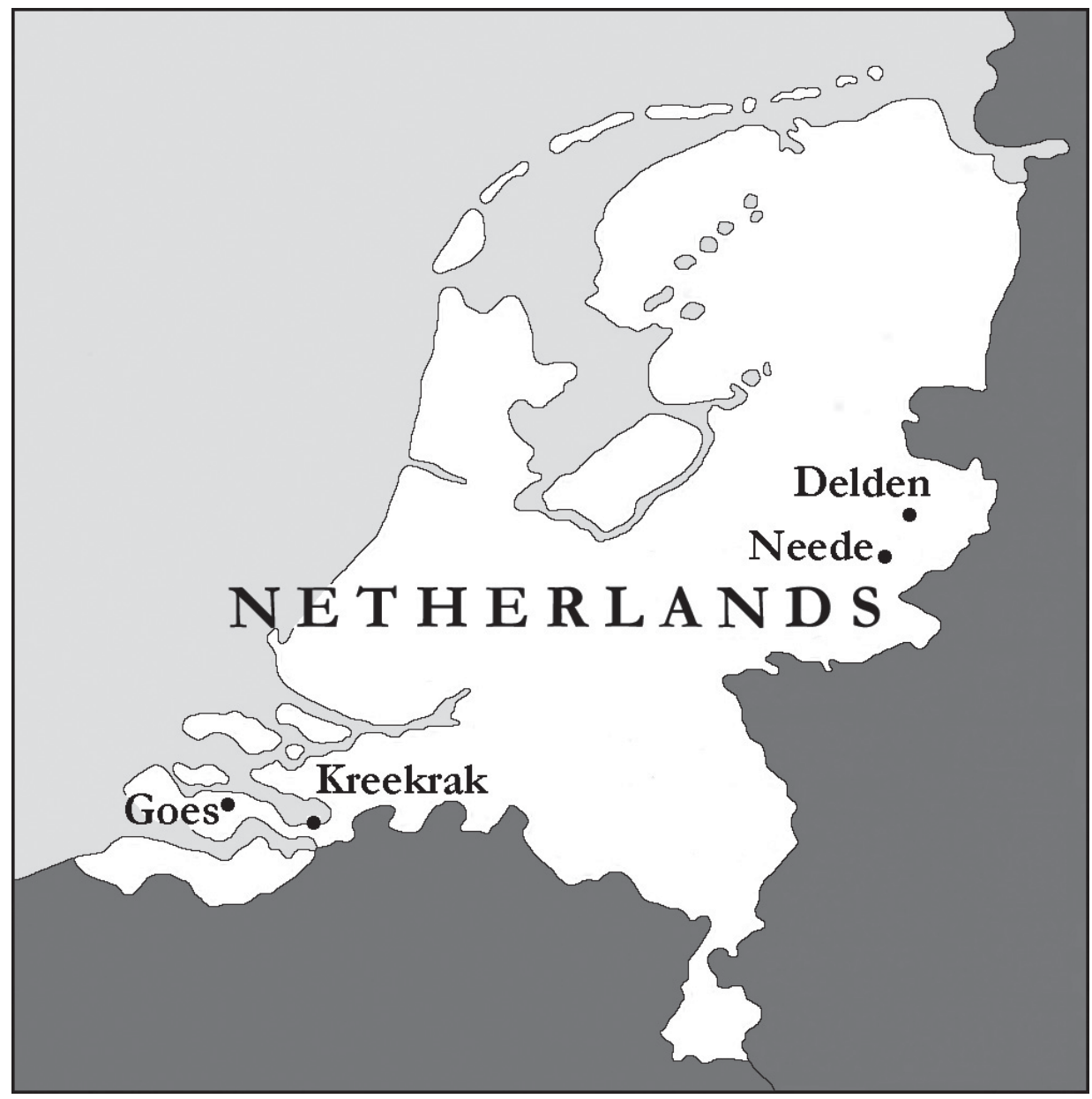

Fig. 4. Location of the studied Dutch Pliocene localities 
Notosaria nysti (Davidson, 1874), 6 fragments, RGM.1309922

Terebratulina retusa (Linnaeus, 1758), 1 specimen with separated brachial and pedicle valve (Figs 49-54), RGM.1309923

Delden (Gelderland), borehole Twickel, Hellecaterveld at Twickelervaart (B28G0201) (old number 28G.3-1), 52.289793 N, 6.700508 E, Early Pliocene, Breda Formation, Delden and Zenderen Member, collected by M. van den Bosch, 21 June 1974. Borehole 28G.3-1 was described in detail and section of the borehole was illustrated by VAN DEN BosCH et al. (1975, Fig. 13). The stratigraphic position of the Delden Member was discussed by Bosch \& WesselingH (2006).

\section{Delden Member:}

3.0-3.5 m: Glottidia cf. dumortieri (Nyst, 1843), > 30 fragments, RGM.793801 3.5-4.0 m: Glottidia cf. dumortieri (Nyst, 1843), > 30 fragments, RGM.793802 4.0-4.5 m: Glottidia cf. dumortieri (Nyst, 1843), > 30 fragments, RGM.793803 5.0-5.5 m: Glottidia cf. dumortieri (Nyst, 1843), > 30 fragments, RGM.793804 5.5-6.0 m: Glottidia cf. dumortieri (Nyst, 1843), > 30 fragments, RGM.793805 6.0-6.5 m: Glottidia cf. dumortieri (Nyst, 1843), > 30 fragments, RGM.793806 6.5-7.0 m: Glottidia cf. dumortieri (Nyst, 1843), > 30 fragments, RGM.793807 7.0-7.5 m: Glottidia? sp., 22 fragments, RGM.793808

Zenderen Member:

7.5-8.0 m: Glottidia? sp., > 30 fragments, RGM.793809

8.0-8.5 m: Glottidia? sp., 5 fragments, RGM.793810

8.5-9.0 m: Glottidia? sp., 5 fragments, RGM.793811

9.0-9.5 m: Glottidia? sp., > 30 fragments, RGM.793812

9.5-10.0 m: Glottidia? sp., 12 fragments, RGM.793813

10.0-10.5 m: Glottidia? sp., 6 fragments, RGM.793814

10.5-11.0 m: Glottidia? sp., 7 fragments, RGM.793815

12.0-12.5 m: Glottidia cf. dumortieri (Nyst, 1843), > 30 fragments, RGM.793816

Neede (Gelderland), borehole Gelselaarsbrug (B34B0175) (old name Neede II, 34B.3-1), 52.164278 N, 6.549397 E, Early Pliocene, Breda Formation, Delden and Zenderen Members, collected by M. van den Bosch, 30 October 1970. Borehole 34B.3-1 was described in detail and the section of the borehole was illustrated by VAN DEN BosCH et al. (1975, Fig. 12); Lingula specimens and Lingula fragments were mentioned along the section.

Delden Member:

32.5-33.5 m: Glottidia? sp., 6 fragments, RGM.793769

33.5-34.5 m: Glottidia? sp., 8 fragments, RGM.793770

34.5-35.5 m: Glottidia? sp., > 10 fragments, RGM.793771

35.5-36.5 m: Glottidia? sp., 1 fragment, RGM.793772 
36.5-37.5 m: Glottidia? sp., 4 fragments, RGM.793773

37.5-38.5 m: Glottidia? sp., > 10 fragments, RGM.793774

38.5-39.5 m: Glottidia? sp., > 10 fragments, RGM.793775

39.5-40.5 m: Glottidia? sp., > 10 fragments, RGM.793776

40.5-41.5 m: Glottidia? sp., > 10 fragments, RGM.793777

41.5-42.5 m: Glottidia? sp., > 10 fragments, RGM.793778

42.5-43.5 m: Glottidia? sp., > 10 fragments, RGM.793779

43.5-45.5 m: Glottidia? sp., > 10 fragments, RGM.793780

45.5-46.5 m: Glottidia? sp., > 10 fragments, RGM.793781

46.5-47.5 m: Glottidia? sp., > 10 fragments, RGM.793782

47.5-48.5 m: Glottidia? sp., 3 fragments, RGM.793783

48.5-49.5 m: Glottidia? sp., 2 fragments, RGM.793784

Zenderen Member:

49.5-50.5 m: Glottidia? sp., 2 fragments, RGM.793785

50.5-51.5 m: Glottidia? sp., 1 fragment, RGM.793786

51.5-52.5 m: Glottidia? sp., 1 fragment, RGM.793787

52.5-53.5 m: Glottidia? sp., 3 fragments, RGM.793788

53.5-54.5 m: Glottidia? sp., 1 fragment, RGM.793789

54.5-55.5 m: Glottidia? sp., 4 fragments, RGM.793790

55.5-56.5 m: Glottidia? sp., 3 fragments, RGM.793791

56.5-58.0 m: Glottidia? sp., 2 fragments, RGM.793792

58.0-59.0 m: Glottidia? sp., 2 fragments, RGM.793793

59.0-60.0 m: Glottidia? sp., 2 fragments, RGM.793794

60.0-61.5 m: Glottidia? sp., 3 fragments, RGM.793795

61.5-62.5 m: Glottidia? sp., 6 fragments, RGM.793796

62.5-63.5 m: Glottidia? sp., 2 fragments, RGM.793797

64.5-66.5 m: Glottidia? sp., 1 fragment, RGM.793798

66.5-67.5 m: Glottidia? sp., 1 fragment, RGM.793799

67.5-68.5 m: Glottidia? sp., 1 fragment, RGM.793800

\section{SYSTEMATIC PALAEONTOLOGY}

Phylum Brachiopoda Duméril, 1806

Subphylum Linguliformea Williams, Carlson, Brunton, Holmer et Popov, 1996

Class Lingulata Gorjansky et Popov, 1985

Order Lingulida Waagen, 1885

Superfamily Linguloidea Menke, 1828

Family Lingulidae Menke, 1828

Genus Glottidia Dall, 1870

Type species - Lingula albida Hinds, 1844 
Glottidia cf. dumortieri (Nyst, 1843)

(Figs 5-9)

1843 Lingula Dumortieri - Nyst, pp. 337-338, Pl. 34, Figs 4a-c.

1872 Lingula Dumortieri Nyst - Wood, pp. 172-173, Pl. 11, Figs 1a-c.

1874 b Lingula Dumortieri Nyst - Davidson, p. 153, Pl. 7, Figs 1-3.

1881 Lingula Dumortieri Nyst - Nyst, p. 252, Pl. 28, Figs 4a-c.

1893 Lingula Dumortieri Nyst - VinCent, pp. 41-42.

1964 Glottidia dumortieri (Nyst) - CHUANG, pp. 155-157, Text-Fig. 1.

2004 Glottidia dumortieri (Nyst) - Vos KUIL, p. 47, Text-Fig. 1.

2013 Glottidia dumortieri (Nyst) - DulAI, pp. 25-26, Figs 6-14.

Material - Gedgrave (159 fragmentary specimens); Delden (Delden Member: $>210$ fragmentary specimens; Zenderen Member: > 30 fragmentary specimens).

Remarks - Although their fossilization potential is rather low (EMIG 1990), remains of lingulid brachiopods are common in the Miocene and Pliocene de-

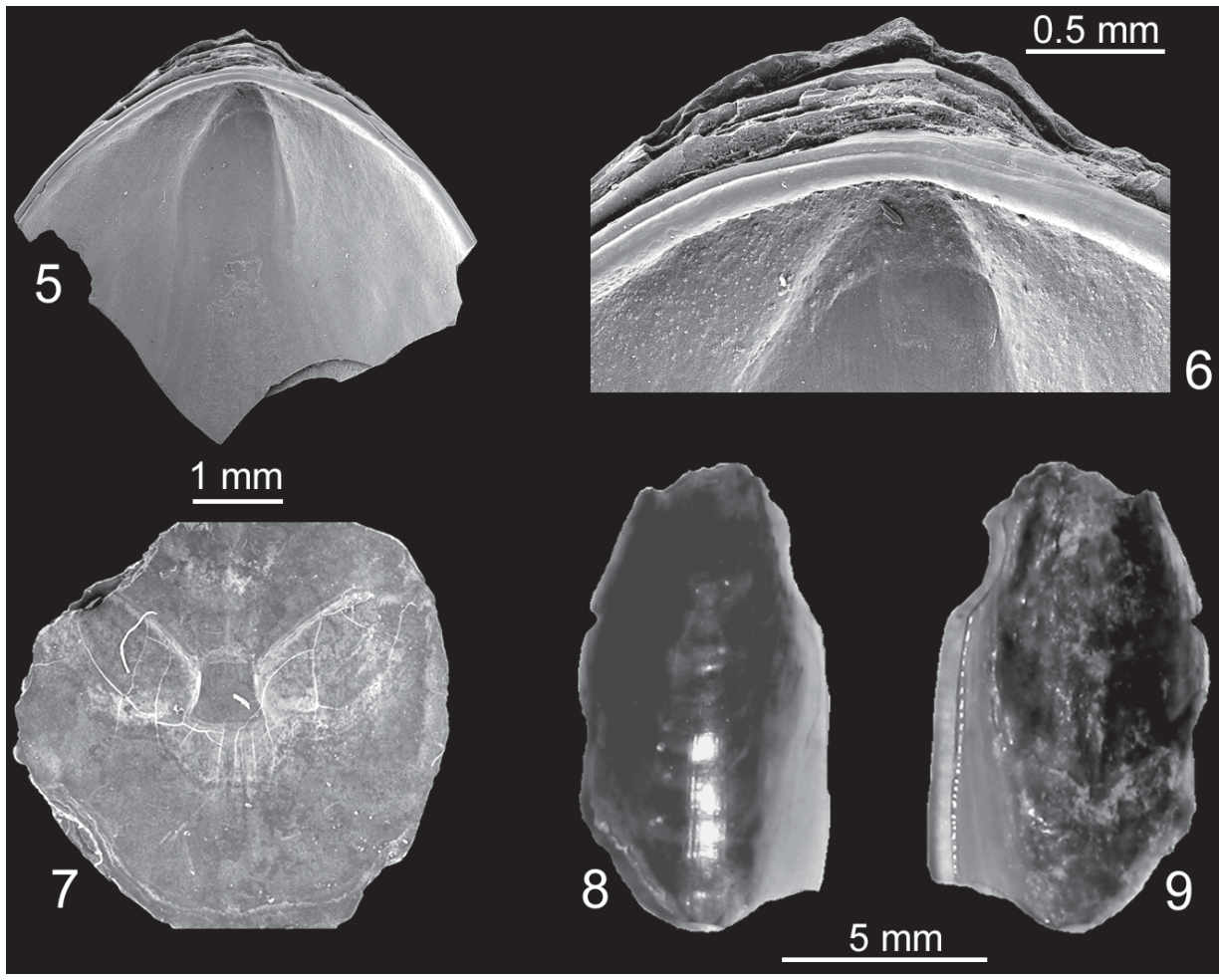

Figs 5-9. Glottidia cf. dumortieri (Nyst, 1843). - 5-6. Gedgrave, 0.55-0.85 m, England, RGM.1309902. - 5. Internal view of dorsal valve. - 6. Detail of Fig. 5. - 7. Internal view of fragmentary valve, Cricqueville-en-Bessin, France, RGM.1309907. - 8-9. Gedgrave, 0.55-0.85 m, England, RGM.793904. - 8. External view. - 9. Internal view 
posits of the North Sea Basin. In several cases these are the dominant fossils, as all or most of the calcium carbonate shells dissolved from the sediments. Species $d u$ mortieri was described from the Pliocene of Belgium by Nyst (1843) as Lingula. This generic assumption was accepted until the mid-1960s, when CHUANG (1964) recognised that this species should be assigned to the genus Glottidia. This classification was confirmed recently by DULAI (2013) on the basis of Miocene samples from the Netherlands (Beugen). Lingula sp. was mentioned several times even recently from the North Sea Basin, but up to now, the only confirmed lingulid brachiopod is Glottidia. Lingula is known from the Miocene of the Central Paratethys (EMig \& Bitner 2005), the Atlantic Ocean in France (EMIg et al. 2007) and from the Mediterranean (DREGER 1911).

The studied samples contain rather fragmentary lingulids, but some of the specimens can be identified clearly as $G$. dumortieri. Lingulids are especially frequent in the two boreholes (Delden and Neede), which yielded samples from the Delden and Zenderen Members of the Breda Formation. The identifiable lingulid specimens are from the Delden Member of Twickel borehole at Delden (Gelderland), while the older Zenderen Member yielded very fragmentary lingulids which were not identifiable at species level. In the case of Gelselaarsbrug borehole at Neede (Gelderland) both members of the Breda Formation contain only very fragmentary lingulids. All of the Coralline Crag samples from Gedgrave contain more or less fragmentary lingulid specimens. Species dumortieri was mentioned from the Coralline Crag as early as Wood (1872) and he realised that it is not rare at Sutton, but all specimens are mutilated.

\section{Glottidia? sp.}

Material - Gedgrave (24 fragments); Cricqueville-en-Bessin (2 fragments); Kreekrak (7 fragments); Delden (Delden Member: 22 fragments, Zenderen Member: > 95 fragments); Neede (Delden Member: > 124 fragments; Zenderen Member: 35 fragments).

Remarks - Several samples from the Pliocene of England, France and the Netherlands yielded indeterminable Lingulidae fragments. The small size of the fragments makes it impossible to decide whether they belong to Lingula or Glottidia. Until now, only Glottidia has surely been confirmed from the Neogene of the North Sea Basin (e.g. ChuANg 1964; Dulai 2013), therefore, Glottidia is used for these fragments with question mark.

Subphylum Rhynchonelliformea Williams, Carlson, Brunton, Holmer et Popov, 1996 Class Rhynchonellata Williams, Carlson, Brunton, Holmer et Popov, 1996 Order Rhynchonellida Kuhn, 1949 
Superfamily Pugnacoidea Rzhonsnitskaia, 1956

Family Basiliolidae Cooper, 1959

Subfamily Aphelesiinae Cooper, 1959

Genus Aphelesia Cooper, 1959

Type species - Anomia bipartita Brocchi, 1814

Aphelesia bipartita (Brocchi, 1814)

(Figs 10-13)

1944 Hemithiris bipartita (Brocchi) - Meznerics, p. 22, Pl. 5, Figs 12, 16.

1944 Hemithiris acuta n. sp. - MeZnerics, pp. 22-23, Pl. 3, Figs 7-10.

1985a Aphelesia bipartita (Brocchi) - Gaetani \& SaccÀ, p. 5, Text-Fig. 2, Pl. 7, Figs 1-4 (cum. syn.).

1985b Aphelesia bipartita (Brocchi) - Gaetani \& SACCÀ, pp. 363-365, Text-Figs 2-3, Pl. 17, Figs 1-3, Pl. 19, Figs 1-3.

2001 Aphelesia bipartita (Brocchi) - BorgHI, pp. 49-50, Pl. 2, Figs 1-5.

2001 Aphelesia bipartita (Brocchi) - Bitner \& MARTINELL, pp. 179-181, Figs 3A-H.

2003 Aphelesia bipartita (Brocchi) - Bitner \& Moissette, p. 466, Figs 2A-M.

2005 Aphelesia bipartita (Brocchi) - GARcía RAmos, pp. 28-29, Pl. 1, Figs 9, 11, Pl. 2, Figs 5, 7.

Material - Ceriale ( 2 complete specimens, 1 pedicle and 1 brachial valve).

Remarks - The few studied specimens from Ceriale are easily recognizable as $A$. bipartita. This species was described in detail by CoOper (1959), GAETANI \& SACCÀ (1985a, b), Bitner \& MARTinell (2001) and Bitner \& Moissette (2003). It is a very significant component of the Terebratula-Aphelesia Bed in Malta (PEDLeY 1976; Dulai et al. in prep.).

Aphelesia is the most common rhynchonellid brachiopod in the European Neogene. It is especially widespread and most diverse in the Mediterranean where three species were recognised in Italy $(A$. bipartita, $A$. margineplicata, $A$. pseudobipartita; GaETANi \& SACCÀ 1985b). Some papers mentioned A. plicatodentata

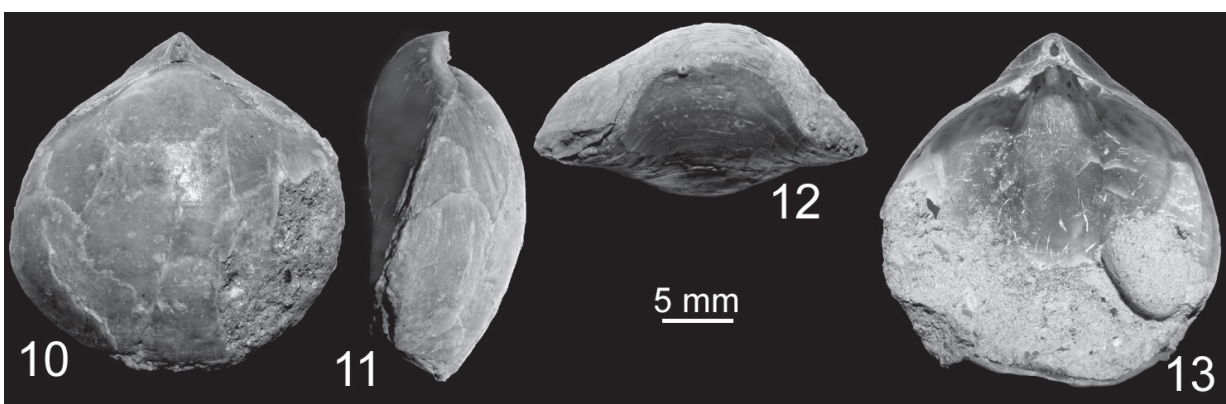

Figs 10-13. Aphelesia bipartita (Brocchi, 1814). - 10-12. Complete specimen from Ceriale, Italy, RGM.1309894. - 10. Dorsal view. - 11. Lateral view. - 12. Anterior view. - 13. Internal view of pedicle valve, Ceriale, Italy, RGM.1309895 
from the Mediterranean Neogene (e. g. Calzada 1978; García Ramos 2004), but it is a junior synonym of $A$. margineplicata (see GAETANI \& SACCÀ 1985b). PAJAUd (1976) described a new genus and new species from the Pliocene of Spain (Phapsirhynchia sanctapaulensis). However, later Phapsirhynchia was synonymized with Aphelesia (Llompart \& Calzada 1982; Gaetani \& SacCá 1985b). GarCía Ramos (2005) went even further and synonymized $A$. sanctapaulensis with $A$. bipartita. An additional new form in the Mediterranean is under description from Malta (Dulai et al. in prep.). A. bipartita was also recognised in the Miocene of the Central Paratethys (Meznerics 1944; Bitner \& DUlai 2004). A. acuta described by Meznerics (1944) from the Middle Miocene (Karpatian) of Hungary is most probably a junior synonym of $A$. bipartita. A separated species (A. winebergeri) was recently erected from the Upper Burdigalian of the Upper Marine Molasse of Southern Germany by BITNER \& SCHNEIDER (2009).

Superfamily Hemithiridoidea Rzhonsnitskaia, 1956

Family Notosariidae Manceñido et Owen, 2001

Genus Notosaria Cooper, 1959

Type species - Terebratula nigricans Sowerby, 1846

Notosaria nysti Davidson, 1874

(Figs 14-18)

1874b Rhynchonella Nysti n. sp. - Davidson, p. 157, Pl. 7, Fig. 17.

1881 Rhynchonella Nysti Davidson - Nyst, p. 250, Pl. 28, Figs 2a-c.

1927 Tegulorhynchia nysti (Davidson) - THOMson, p. 153.

1959 Notosaria nysti (Davidson) - Cooper, p. 49.

1979 Notosaria nysti (Davidson) - LeE \& WiLson, p. 439.

1987 Tegulorhynchia nysti (Davidson) - OTtema \& IN'T Hout, p. 76, Fig. 4.

Material - Kreekrak ( 1 complete specimen, 3 brachial valves; 6 fragments).

Remarks $-N$. nysti was originally described by Davidson (1874b) from the "Scaldisien" (= Pliocene, Late Zanclean to Piacenzian; LAGA \& Louwye 2006) of Antwerp, Belgium. Unfortunately, DAvidson (1874b) had very limited material and illustrated only the ventral valve, but mentioned its close similarity to Rh. nigricans. CHAPMAN \& CRESPIN (1923) erected a new genus Tegulorhynchia for ribbed rhynchonellids of the southern hemisphere, and some years later THOMson (1927) attributed species nysti to Tegulorhynchia. CoOper (1959) described a new genus, Notosaria with type species Terebratula nigricans, and distinguished his new genus from Tegulorhynchia on the basis of ornamentation, beak characters and cardinalia. Cooper also studied a pedicle and a brachial valve of Rh. nysti confirming DAVIDSON's (1874b) original observation and included this species also to his new genus, Notosaria. Later LeE \& Wilson (1979) 
accepted and followed this opinion. The new, revised Treatise also mentioned Notosaria from Europe (Middle Miocene of Poland and Pliocene of Belgium) (MANCEÑIDo et al. 2002) and erected the new family Notosariidae. The only Miocene record of Notosaria from Europe is an eroded and very uncertain pedicle valve from Poland (POPIEL-BARCZYK \& BARCZYK 1990).

This species has not been illustrated since DAvidson's (1874b) original description (his figures were re-published by NYST 1881), although it is not rare in some Neogene assemblages. OттемA \& in't Hout (1987) probably also redrew DAVIDson's (1874b) pedicle valve illustrations, which is rather strange, as this species is common in the studied Kallo assemblage. VINCENT (1893) mentioned species nysti from Belgium, while Dolfuss \& Dautzenberg (1901) and DE MoRGAN (1915) reported it from the Miocene of France (Savigné, SaintSaturnin, Saint-Emy) without illustrations. In the studied material this species occurs in the Kreekraksluizen sample only with some valves, but it is common in some Pliocene ("Redonian") samples of France (e.g. St. Clément-de-la Place) or in the Pliocene of Belgium (e.g. Kallo). The detailed description of both of these faunas is in progress and emended diagnosis of $N$. nysti will be given there.

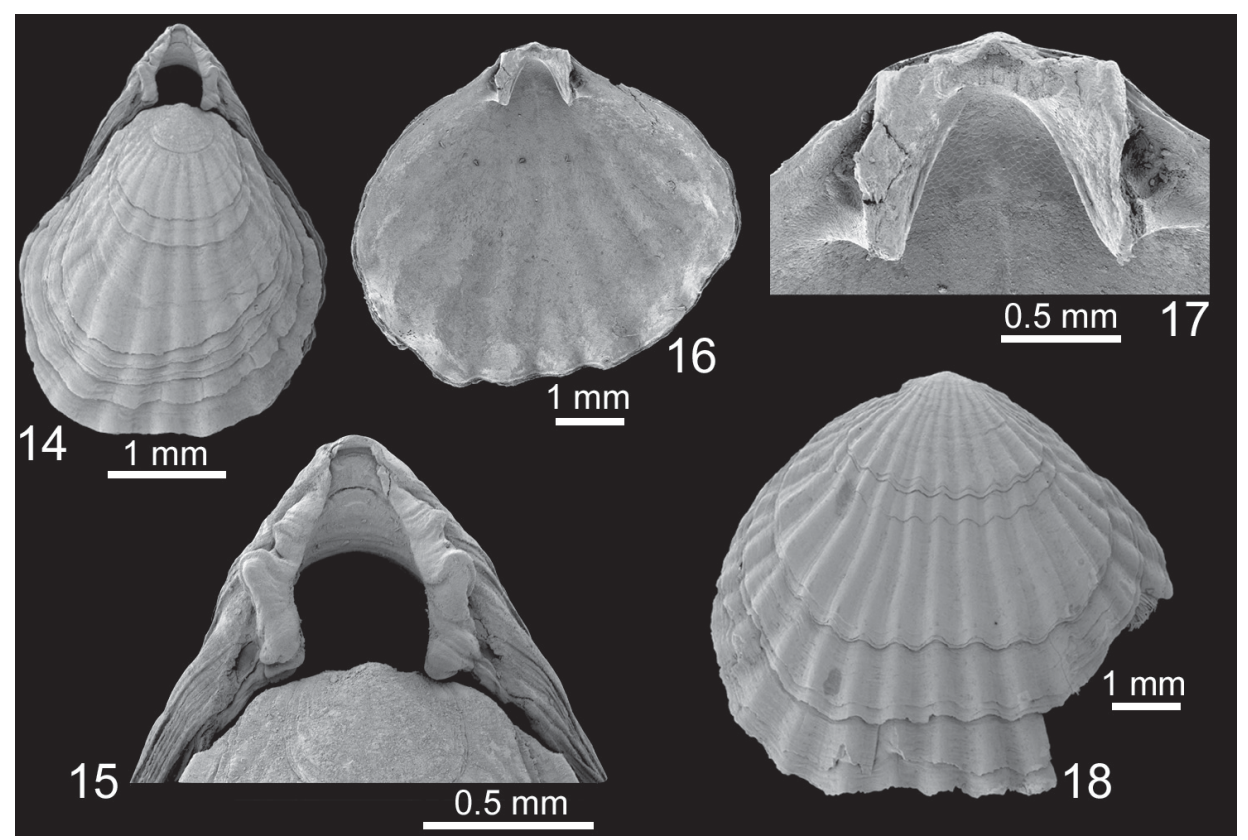

Figs 14-18. Notosaria nysti Davidson, 1874, Kreekrak (47-50 m), the Netherlands. - 14. Complete juvenile specimen, RGM.1309924, dorsal view. - 15. Detail of Fig. 14, showing the beak region of the specimen. - 16. Brachial valve, RGM.1309925, internal view. - 17. Detail of Fig 16. - 18. Brachial valve, RGM.1309926, external view 
Order Terebratulida Waagen, 1883

Suborder Terebratulidina Waagen, 1883

Superfamily Terebratuloidea Gray, 1840

Family Terebratulidae Gray, 1840

Subfamily Terebratulinae Gray, 1840

Genus Terebratula Müller, 1776

Type species - Anomia terebratula Linnaeus, 1758

Terebratula ampulla (Brocchi, 1814)

(Figs 19-26, 27-34)

1983 Terebratula ampulla (Brocchi) - Cooper, Pl. 4, Figs 8-16.

2001 Terebratula ampulla (Brocchi) - Borghi, pp. 51-52, Pl. 3, Figs 2, 3, 4, 6, 7, Pl. 4, Fig. 1.

2004 Terebratula ampulla (Brocchi) - García RAmos, pp. 21-23, Pl. 5, Figs 3, 7, 8, 9, 10, Pl. 6, Fig.

3, Pl. 7, Figs 3, 4, 5, 6, 7, 9 .

2008 Terebratula ampulla (Brocchi) - TADDEI Ruggiero et al., p. 211, Figs 1H-M.

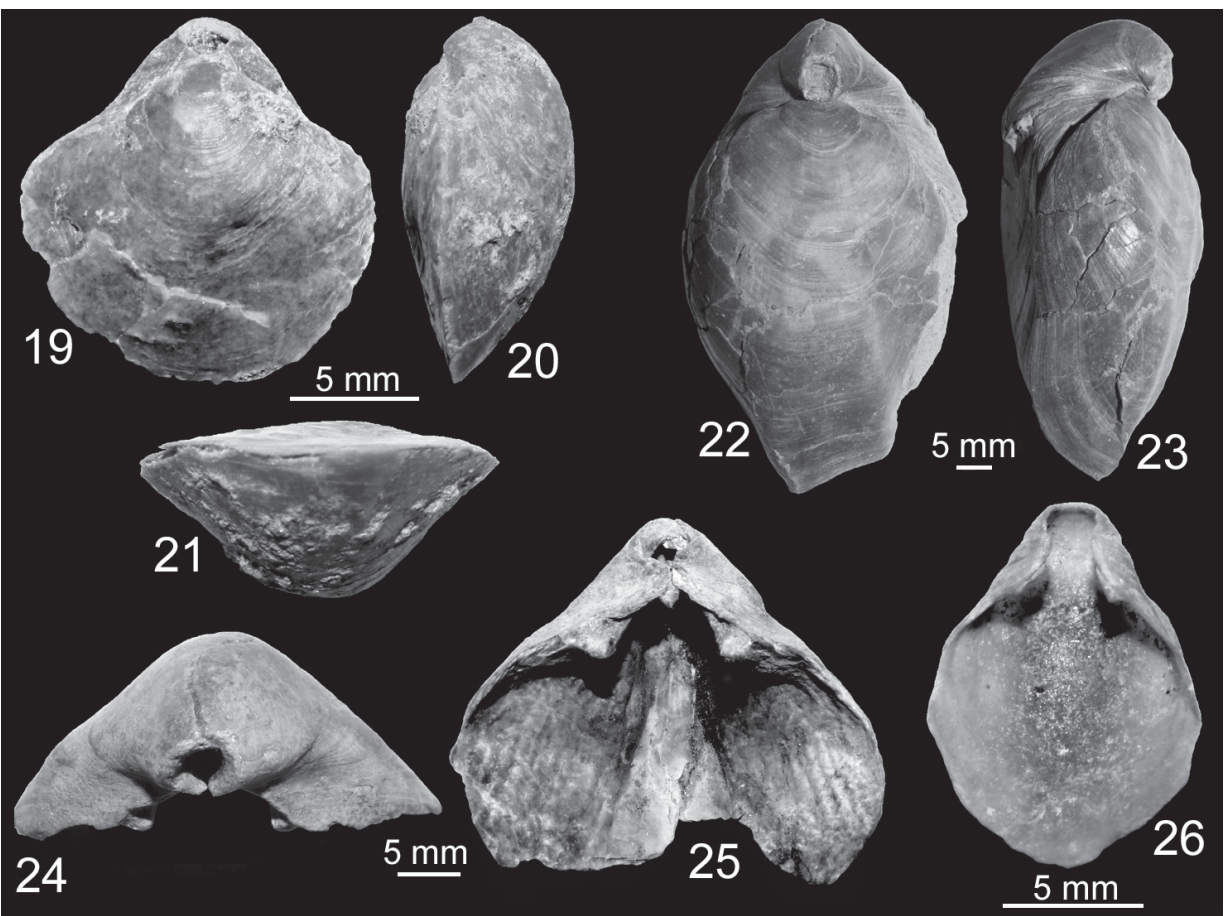

Figs 19-26. Terebratula ampulla (Brocchi, 1814). - 19-21. Complete specimen, Valle Andona, Italy, RGM.1309882. - 19. Dorsal view. - 20. Lateral view. - 21. Anterior view. - 22-23. Complete specimen, Ceriale, Italy, RGM.1309897. - 22. Dorsal view. - 23. Lateral view. - 24-25. Fragmentary pedicle valve, Lugagnano, Italy, RGM.1309885. - 24. Posterior view. - 25. Internal view. - 26. Internal view of pedicle valve, Valle Andona, Italy, RGM.1309883 


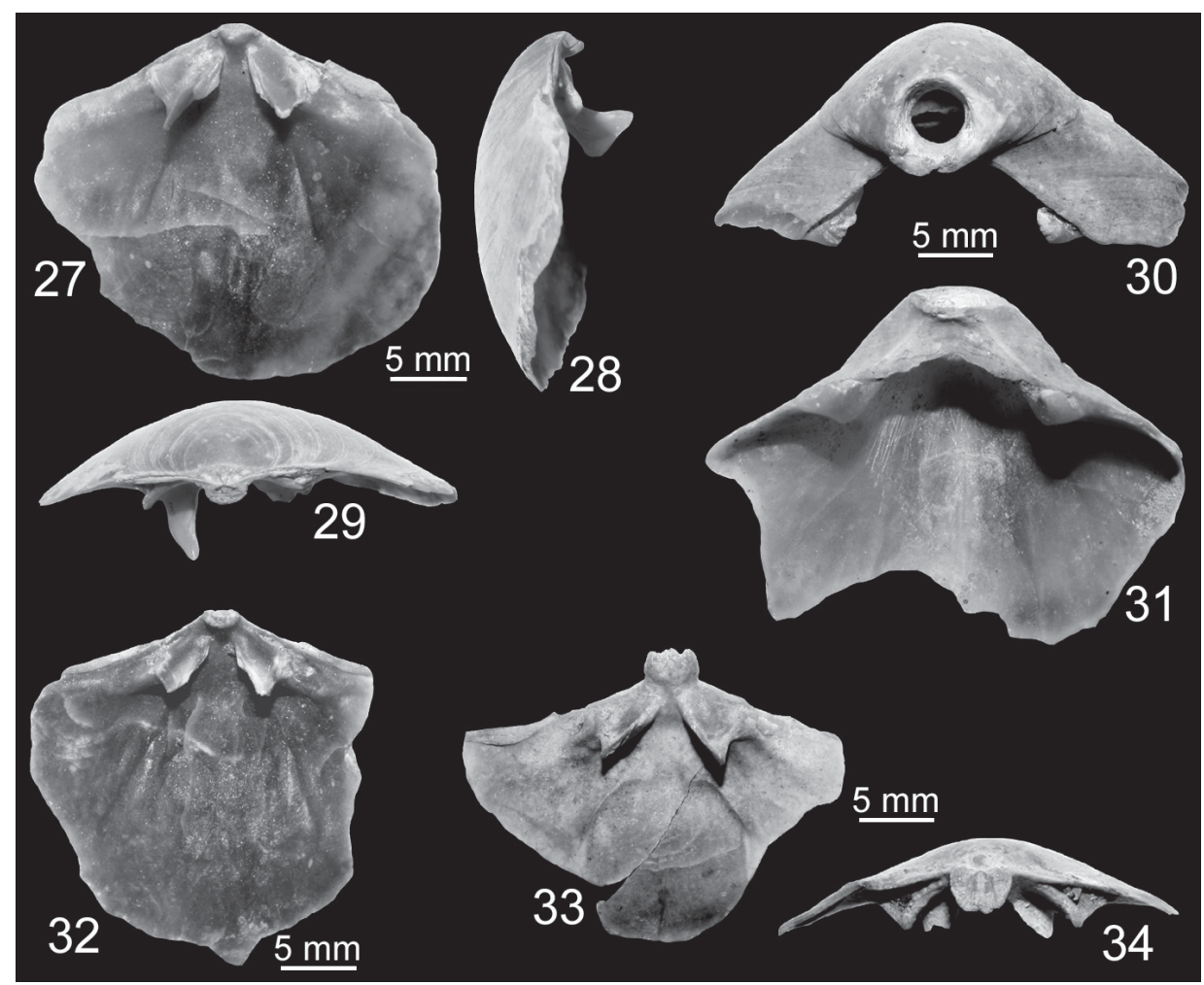

Figs 27-34. Terebratula ampulla (Brocchi, 1814). - 27-29. Brachial valve, San Nicomede, Italy, RGM.1309888. - 27. Internal view. - 28. Lateral view. - 29. Posterior view. - 30-31. Fragmentary pedicle valve, San Nicomede, Italy, RGM.1309889. - 30. Posterior view. - 31. Internal view. - 32. Internal view of fragmentary brachial valve, showing the elongated muscle scars, San Nicomede, Italy, RGM.1309890. - 33-34. Fragmentary brachial valve, San Nicomede, Italy, RGM.1309892. -

33. Internal view. - 34. Posterior view

Material - Valle Andona (1 complete specimen, 4 pedicle valves); Lugagnano ( 4 pedicle valves); San Nicomede ( 7 pedicle and 8 brachial valves); Ceriale ( 3 complete specimens, 9 pedicle and 9 brachial valves); Apricena ( 2 pedicle valves and 1 brachial valve).

Remarks - Terebratula and its type species T. terebratula were revised and discussed in detail by LEE et al. (2001). In this paper several species were synonymized with $T$. terebratula, however, the validity of $T$. ampulla as a medium-sized, strongly bisulcate species from the Pliocene was confirmed. TADDEI RUGGIERO et al. (2008) have accomplished a morphometric study on Late Cenozoic Terebratula from Italy, in which T. terebratula, T. ampulla, T. scillae and T. sinuosa were compared. According to their results, T. ampulla is distinct from T. scillae/T. terebratula in ante- 
rior view, because it is much more compressed dorsoventrally. In dorsal view T. ampulla is readily distinguished because of its pentagonal shape (TADDEI RUGGIERO et al. 2008). T. ampulla is widespread in the Pliocene of the Mediterranean (e.g. Borghi 2001; García Ramos 2004; TAddei Ruggiero et al. 2008). Some papers (e.g. BossElAERs et al. 2004) mentioned this species also from the Neogene of the North Sea Basin, but until now, these records have not been confirmed.

The beak area of several San Nicomede pedicle valves is strongly eroded and the foramen is significantly widened. In the case of Ceriale samples, all complete specimens are strongly compressed, the separated pedicle valves are intact but sometimes fragmentary. The middle part of the smallest complete specimen and edge of two pedicle valves show small-sized traces of predatory organisms. A small worm tube encrustation can be seen on the internal surface of a pedicle valve.

Genus Pliothyrina van Roy, 1980

Type species - Terebratula sowerbyana Nyst, 1843

Pliothyrina sowerbyana (Nyst, 1843)

(Figs 35-48)

1843 Terebratula Sowerbyana - Nyst, pp. 335-336, Pl. 27, Figs 3a-b.

1980 Pliothyrina sowerbyana (Nyst) - VAN Roy, pp. 3-7, Pl. 1, Figs 1-7, Pl. 2, Figs 1-7.

1983 Pliothyrina sowerbyana (Nyst) - Cooper, pp. 237-238, Pl. 5, Figs 1-4.

2004 Pliothyrina sowerbyana (Nyst) - Vos KuIL, pp. 50-53, Text-Figs 7A-L.

Material - Gedgrave (3 complete specimens, 50 pedicle and 50 brachial valves); Brightwell (1 brachial valve); Cricqueville-en-Bessin (1 complete specimen, 6 pedicle and 5 brachial valves); Goes ( 2 pedicle valves and 1 brachial valve, 6 fragments).

Remarks - Large-sized Miocene and Pliocene terebratulids have a long and complex nomenclatural history in the North Sea Basin. Several names were introduced in the literature both in the eastern (Belgium - the Netherlands) and in the western (Great Britain) part of the Basin. It seems that nearly all, or at least most of the Oligocene-Pliocene large terebratulids belong to the genus Pliothyrina described by VAN RoY (1980) with type species P. sowerbyana. LACOURT (1983) identified 30 names for Terebratulidae species from the Neogene of the Netherlands (mentioning even some Mesozoic species). Later Vos KUIL (2004) revised LACOURT's (1983) work, and correctly synonymized nearly all of his terebratulids with $P$. sowerbyana. The only exception was "Terebratula" distinguenda Lacourt, 1984, which was separated with question mark also by Vos KUIL (2004). On the basis of some Dutch private collections (Freddie van Nieulande, Peter Mordijk, Harry Raad) this separate species with very small pedicle opening really exists, and its internal morphology 


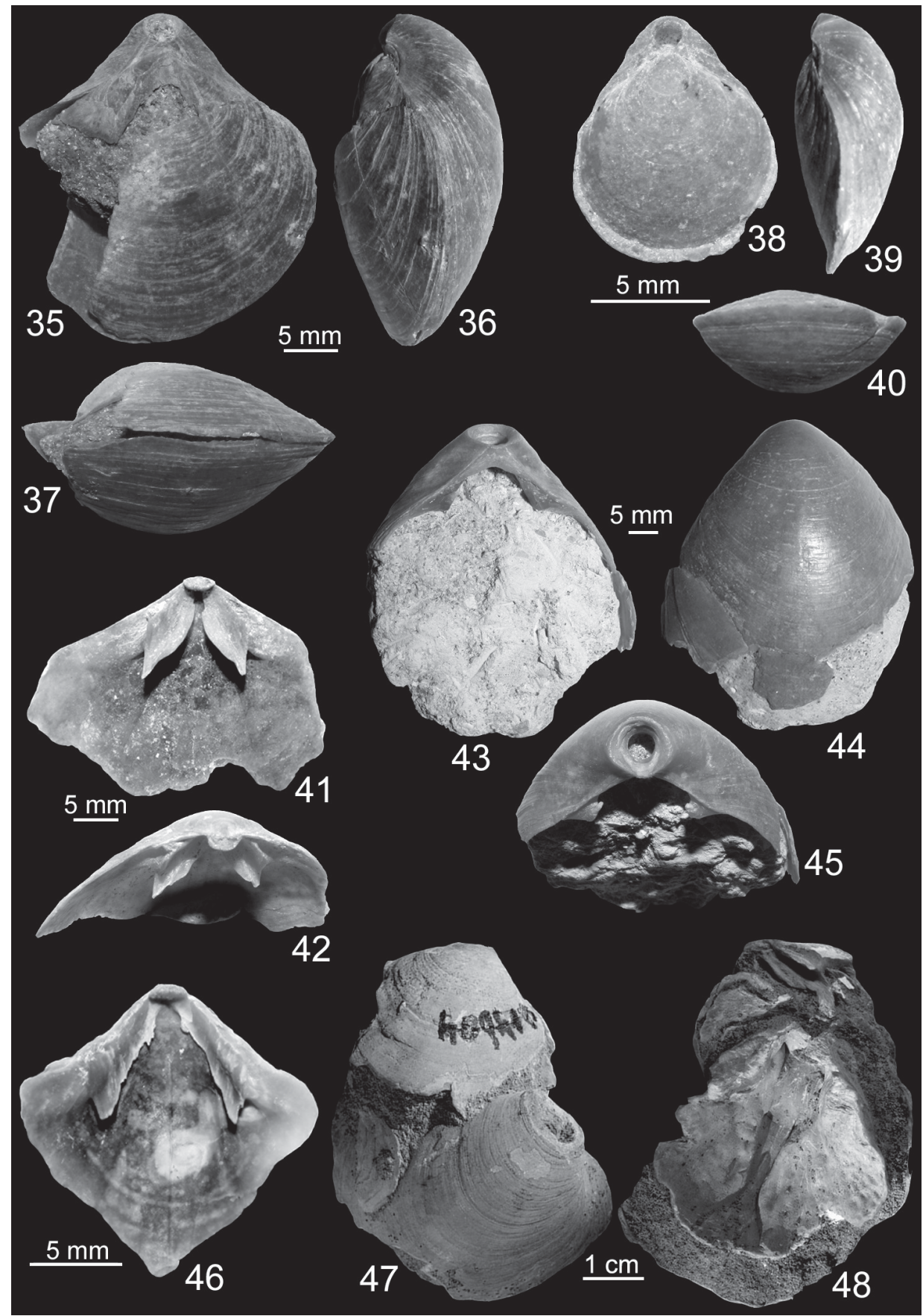


is also significantly different from Pliothyrina, and refers to a separate, new genus. This new taxon hopefully will be described in the near future, in the framework of the cooperation with the above mentioned private collectors.

After van Roy's (1980) description, the name Pliothyrina sowerbyana became widely accepted and well-known, and several papers used this name for large terebratulids in the North Sea Basin (e.g. Vos KUIL 2004; MoERdiJ K 2007; RAAD 2004a, b, 2008; VAN Nieulande 2009). However, recently MoerdijK (2016) discussed in detail the nomenclatural problems of Neogene Pliothyrina assemblages of the North Sea Basin. The correct name of the very common and wide-spread form is under discussion, and until the final decision the well-known name $P$. sowerbyana is used in this paper.

HeRMAN in Bosselaers et al. (2004) indicated Terebratula ampulla together with $P$. sowerbyana and Lingula sp. (= Glottidia) in the Late Miocene of Belgium, illustrated by the dorsal view of a fragmentary specimen (p. 32, Fig. 5c). VAN NiEULANDE (2009) also mentioned $P$. sowerbyana and Terebratula sp. from the "seashore strands". However, until now, the presence of Terebratula or specifically T. ampulla has not been confirmed in the North Sea Basin; it is a typical Mediterranean taxon.

\title{
Pliothyrina? sp.
}

Material - Gedgrave (177 fragments); Goes (1 fragment).

Remarks - The Coralline Crag samples from Gedgrave contain several smallsized, unidentifiable smooth Terebratulidae fragments. As Pliothyrina sowerbyana specimens are common in these beds, these fragments are regarded as Pliothyrina sp. with question mark.

\author{
Superfamily Cancellothyridoidea Thomson, 1926 \\ Family Cancellothyrididae Thomson, 1926 \\ Subfamily Cancellothyrininae Thomson, 1926 \\ Genus Terebratulina d'Orbigny, 1847 \\ Type species - Anomia retusa Linnaeus, 1758
}

Figs 35-48. Pliothyrina sowerbyana (Nyst, 1843). - 35-37. Nearly complete specimen, Gedgrave, 0.85-1.00 m, RGM.793908, England. - 35. Dorsal view. - 36. Lateral view. - 37. Anterior view. 38-40. Complete juvenile specimen, Gedgrave, 0.55-0.85 m, England, RGM.793903. - 38. Dorsal view. - 39. Lateral view. - 40. Anterior view. - 41-42. Fragmentary brachial valve, Gedgrave, 1.7-1.9 m, England, RGM.793921. - 41. Internal view. - 42. Posterior view. - 43-45. Fragmentary pedicle valve, Gedgrave, 0.85-1.0 m, England, RGM.793907. - 43. Internal view. - 44. External view. - 45. Posterior view. - 46. Internal view of fragmentary brachial valve, Cricquevilleen-Bessin, France, RGM.1309909. - 47-48. 2 pedicle valves, 1 brachial valve, Goes, $74 \mathrm{~m}$, the Netherlands, RGM.14604. - 47. External view. - 48. Internal view 


\section{Terebratulina retusa (Linnaeus, 1758)}

(Figs 49-54)

1852 Terebratulina caput-serpentis Linnaeus - Davidson, pp. 12-14, Pl. 1, Figs 3-6, 14-15.

1979 Terebratulina retusa (Linnaeus) - BRUnTon \& CURRY, p. 38, Text-Figs 17A-C.

1985a Terebratulina retusa (Linnaeus) - GAETANi \& SACCÀ, pp. 15-16, Pl. 7, Figs 5-10, Pl. 9, Figs

6-9 (cum syn.).

2001 Terebratulina retusa (Linnaeus) - Borghi, p. 52, Pl. 4, Figs 4, 5, 6, 7, 8.

2003 Terebratulina retusa (Linnaeus) - BITNER \& MoIssetTe, p. 472, Figs 6A-F.

2004 Terebratulina retusa (Linnaeus) - Vos KUIL, p. 49, Text-Figs 4A-G.

2004 Terebratulina retusa (Linnaeus) - García Ramos, p. 28, Pl. 1, Figs 1-3.

2007 Terebratulina retusa (Linnaeus) - Koskeridou, pp. 124-125, Pl. 1, Figs 5-6.

Material - Apricena (1 complete specimen); Kreekrak (1 complete specimen, 1 brachial valve).

Remarks - T. retusa is a common member of Neogene and Recent benthic assemblages, however, much more frequent in deeper water environments. Depth range of Recent T. retusa is very wide (18-2157 m; LogAN 2007), but it is the most common between 100 and 500 m (CURRY 1982). According to LogAN (1979)

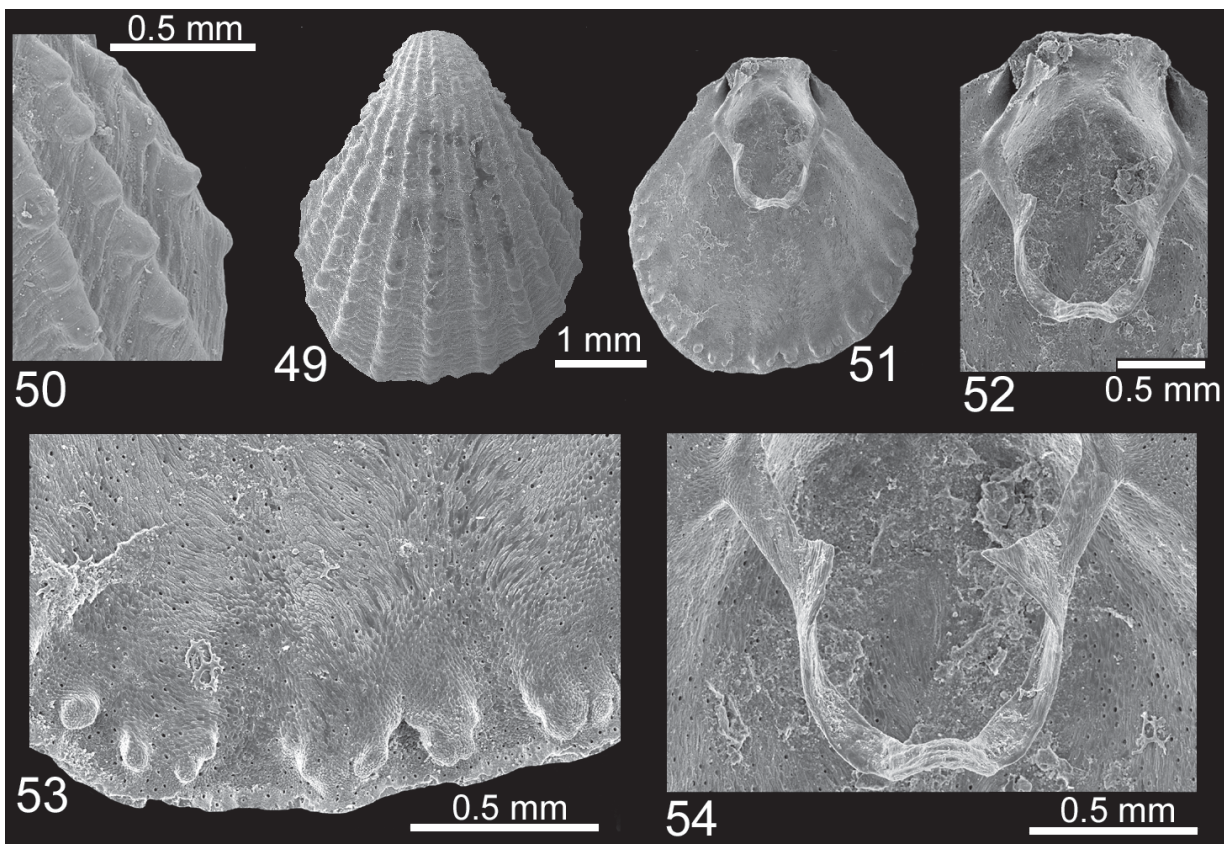

Figs 49-54. Terebratulina retusa (Linnaeus, 1758), Kreekrak, the Netherlands, separated valves of the same specimen, RGM.1309923. - 49-50. Pedicle valve. - 49. External view. - 50. Detail of external surface ornamentation. - 51-54. Brachial valve. - 51. Internal view. - 52. Brachidium. 53. Detail of the anterior margin of brachial valve. -54 . Detail of brachidium 
and Logan et al. (2004) Terebratulina (together with Gryphus, Platidia and Megerlia) belongs to the eurybathic species which are more typical of the bathyal zone in the Recent Mediterranean. Probably this is the reason that this species is very rare in the studied samples, both in the Mediterranean and the North Sea Basin. T. retusa is consistently cited from the Neogene of the Mediterranean (e.g. Gaetani \& Saccà 1985a; Taddei Ruggiero 1994; Borghi 2001; Bitner \& Moissette 2003; García Ramos 2004; Koskeridou 2007) and known from the Central Paratethys (e.g. Bitner \& Dulai 2004). More rarely it was also mentioned from the North Sea Basin Neogene (DAvidson 1852; Wood 1872) and Recent (BRUNTON \& CURRY 1979; CURRY 1982) assemblages, sometimes under the name $T$. caputserpentis. The complex nomenclatural history of the retusa caputserpentis problem was discussed recently in detail by EMIG et al. (2015).

Suborder Terebratellidina Muir-Wood, 1955

Superfamily Zeillerioidea Allan, 1940

Family Zeilleriidae Allan, 1940

Subfamily Macandreviinae Cooper, 1973

Genus Macandrevia King, 1859

Type species - Terebratula cranium Müller, 1776

Macandrevia cranium (Müller, 1776)

(Figs 55-60)

1886 Waldheimia (Macandrevia) cranium (Müller) - DAvidson, pp. 61-66, Pl. 12, Figs 11-23, Pl. 13 , Figs $1-2$.

1979 Macandrevia cranium (Müller) - BRUNTON \& CURRY, p. 58, Figs 30A-C.

1990 Macandrevia cranium (Müller) - Thomsen, p. 25, Text-Fig. 1.

2001 Macandrevia cranium (Müller) - Thomsen, pp. 121-123, Text-Fig.

2004 Macandrevia cranium (Müller) - Vos Kuil, pp. 49-50, Text-Figs 5A-G.

2012 Macandrevia cranium (Müller) - ZEZINA, p. 86.

Material - Gedgrave ( 2 complete specimens, 3 pedicle valves); Cricquevilleen-Bessin ( 2 pedicle valves); Kreekrak (1 pedicle valve, 1 brachial valve).

Remarks - Today Macandrevia cranium is known mainly from the Arctic region (Western Arctic, Greenland, Norway, Northern Atlantic, Spitzbergen, Greenland, Rhode Island, and Western Sahara) but may occur also in the Mediterranean (Lion Bay, France) (ZEZINA 2012). M. cranium has a long nomenclatural history, and earlier it was attributed to different genera: Terebratula (MÜLLER 1776; JefFreys 1878), Waldheimia (DAvidson 1886; Fischer \& Oehlert 1891; Posselt 1898); Waldheimiathyris (Wesenberg-Lund 1941). Dall (1920) described a new species, $M$. novangliae which is generally synonymized with $M$. cranium (e.g. ZeZINA 2012). Thomsen (1990) studied $M$. cranium and its usefulness 


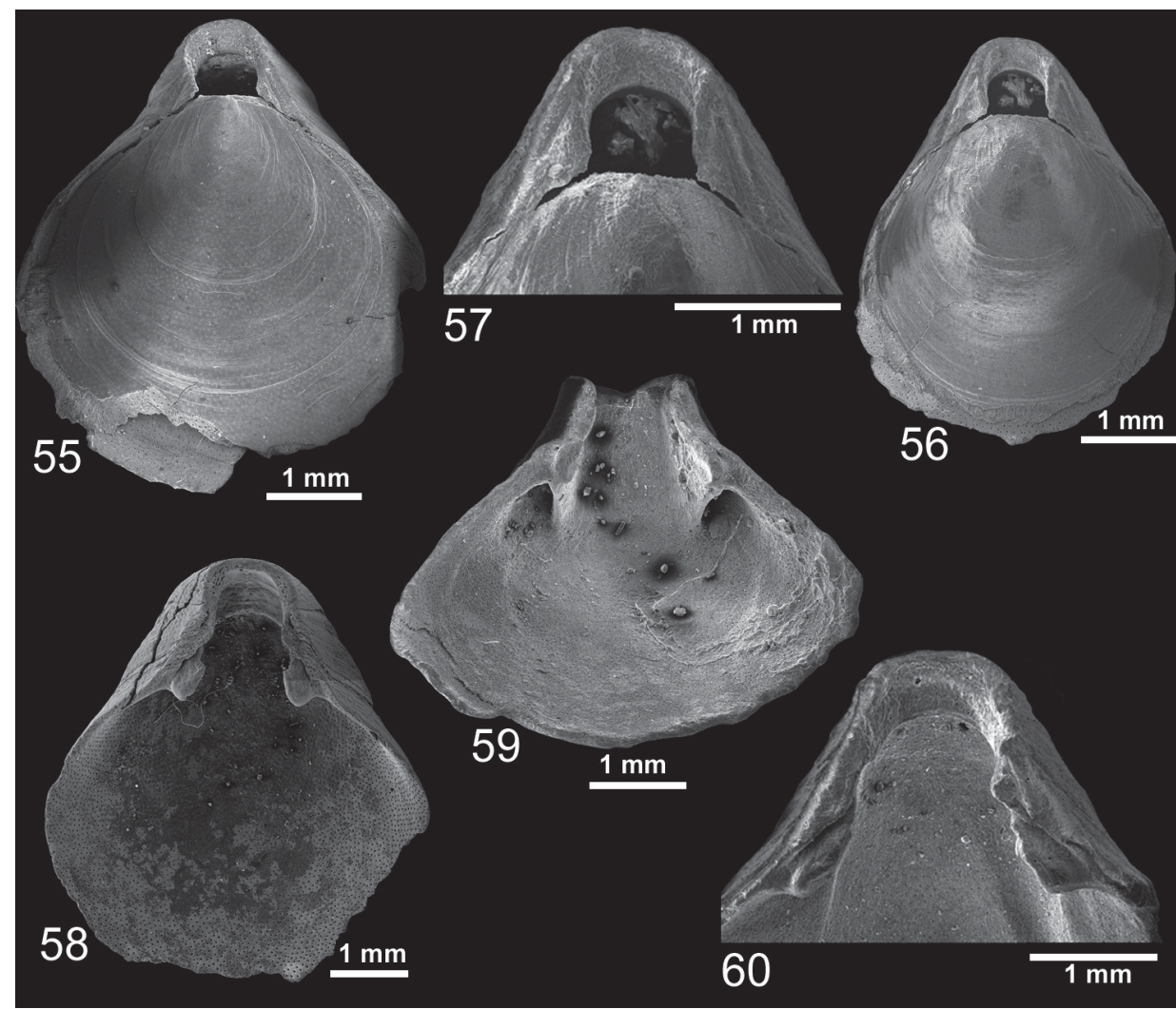

Figs 55-60. Macandrevia cranium (Müller, 1776). - 55. Dorsal view of juvenile specimen, Gedgrave, 1.7-1.9 m, England, RGM.1309906. - 56-57. Juvenile specimen, Gedgrave, 0.55-0.85 m, England, RGM.1309904. - 56. Dorsal view. - 57. Detail of Fig. 56 showing the pedicle opening. - 58. Internal view of pedicle valve, Cricqueville-en-Bessin, France, RGM.1309914. - 59. Internal view of fragmentary pedicle valve, Gedgrave, 0.55-0.85 m, England, RGM.1309905. - 60. Internal view of pedicle valve showing the beak area, Gedgrave, 1.00-1.25 m, England, RGM.1309917

in palaeoceanographic reconstructions. It belongs to the deep-water forms, the recent representatives are known from 9-2951 m (ZEZINA 2012). In the studied North Sea Basin samples it consistently occurs in small specimen numbers.

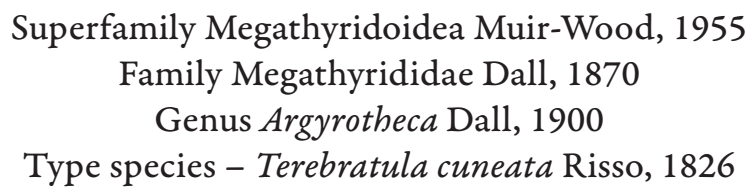




\section{Argyrotheca cf. plicata (de Morgan, 1915)}

(Figs 61-64)

Material - Cricqueville-en-Bessin (1 pedicle valve).

Remarks - Unfortunately, the available material is very limited, contains only a pedicle valve. It is very similar to DE MORGAN's (1915) species, which was described from the Middle Miocene (Langhian) of Pontlevoy as a rare new species. This species was also listed by PACAUD (2014) among brachiopod type specimens of the Natural History Museum in Paris, without any additional information. The main difference between them that de Morgan's specimen has rounded outline, while the Cricqueville-en-Bessin specimen is more subtrigonal. The other characters are the same (few weak and rounded ribs, lack of tubercles along the in-

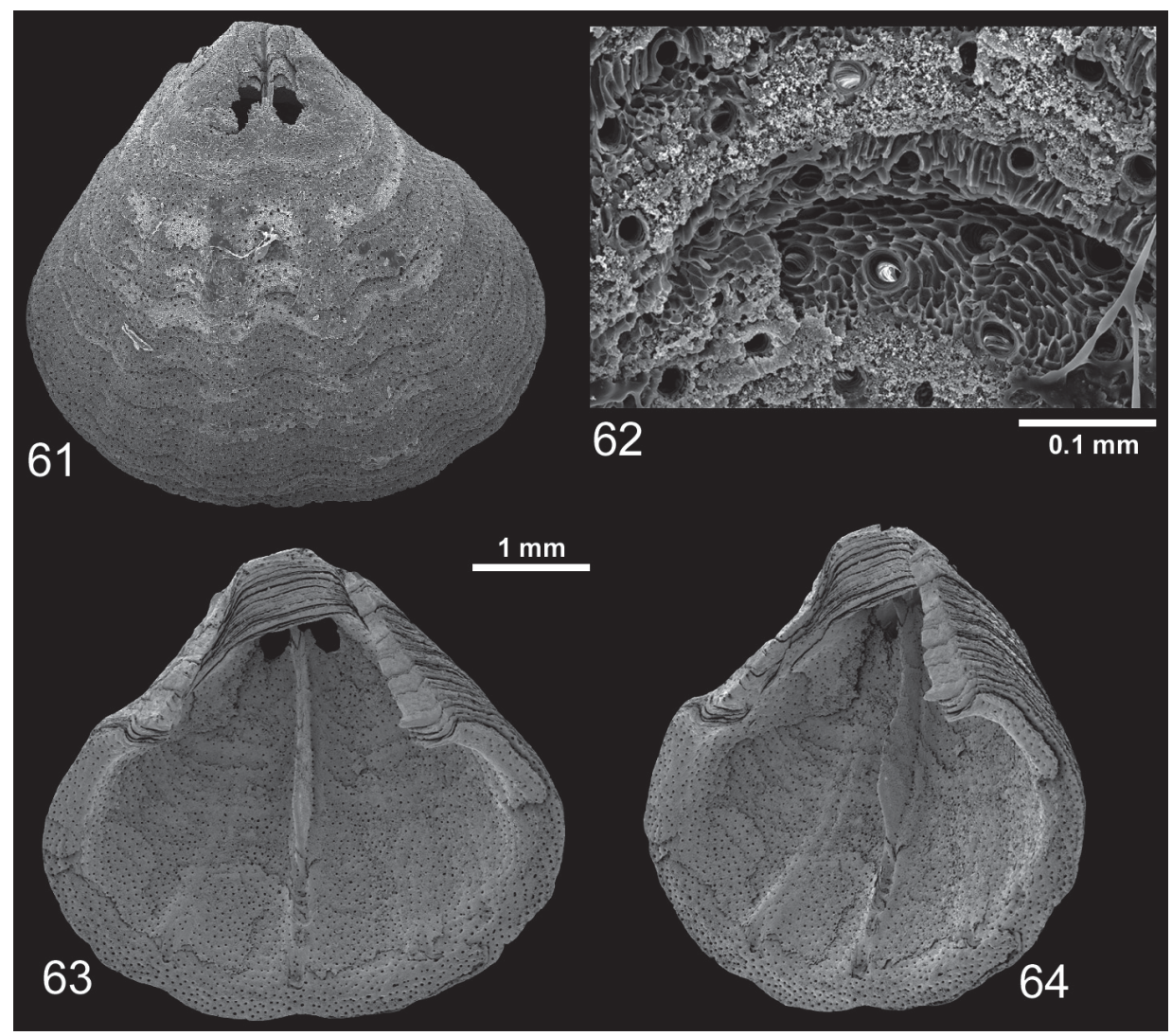

Figs 61-64. Argyrotheca cf. plicata (de Morgan, 1915), Cricqueville-en-Bessin, France. - 61. External view of pedicle valve. $\mathbf{6 2}$. Detail of Fig. 61, showing the shell structure. $\mathbf{6}$ 63. Internal view of pedicle valve. $\mathbf{6 4}$. Oblique lateral view of pedicle valve 
ternal margin of the valve, short and low median septum in the pedicle valve). Reasonable interpretation of this form requires much more available material.

\section{CONCLUSIONS}

The Cenozoic Mollusc collection of the Naturalis Biodiversity Center has rich and diverse Pliocene materials which contain some brachiopods, too. The numerous and diverse brachiopod collections (e.g. "Redonian" of France, or "Kattendijkian" of Belgium) will be published in separate papers, but some rare and sporadic samples are also worthwhile to publish. These sporadic samples are from the Italian part of the Mediterranean and from different parts of the North Sea Basin (Coralline Crag and Red Crag samples from England, single sample from North France, and some borehole materials from the Netherlands).

The studied samples altogether yielded more than 1000 specimens which represent 8 species of 8 genera. The Italian Pliocene assemblage is dominated by large terebratulids (all of them belong to Terebratula ampulla), while characteristic rhynchonellids (some Aphelesia bipartita) and cancellothyridids (only one Terebratulina retusa) are rare. The Coralline Crag samples of England are characterized by the very fragmentary specimens of large terebratulids. For the present the well-known and widely applied name Pliothyrina sowerbyana is used but the correct name for North Sea Basin Pliocene large terebratulids is under discussion (see e.g. MOERDIJ K 2016). Fragmentary lingulids are also common in these samples, and until now only the presence of Glottidia dumortieri has been confirmed in the Neogene of the North Sea Basin. The zeilleriid Macandrevia cranium is rarely found in Crag samples. The only French locality, Cricqueville-en-Bessin yielded few brachiopods, but relatively higher diversity. The terebratulid $P$. sowerbyana is more common, while all the others are rare: G. dumortieri, M. cranium, Argyrotheca cf. plicata. The Dutch Pliocene samples are dominated by mostly fragmentary lingulids, $G$. dumortieri. The others are much less common (Notosaria nysti, P. sowerbyana, T. retusa, M. cranium). N. nysti is rare and only shortly discussed from these samples, and will be described in detail in the near future on the basis of French ("Redonian") and Belgian ("Kattendijkian") materials. However, this is the first photo documentation of this species, as until now it has rarely been described, and has been illustrated only by drawings (DAVIDSON 1974b; NYST 1881; OtTEMA \& IN'T Hout 1987).

Acknowledgements - This study was supported by the European Commission's Research Infrastructure Action (Synthesys project NL-TAF-3270) and the Hungarian Scientific Reasearch Fund (OTKA K112708). Study of C. plicata type specimens in the Natural History Museum, Paris was possible by the support of another Synthesys project (FR-TAF-4689). Frank Wesselingh's help within the Cenozoic Mollusc Collection of Naturalis Biodiversity Center is greatly acknowledged. 
I thank Ronald Pouwer collection manager for discussion on NBC samples and localities. The SEM micrographs were taken in the SEM Laboratory of the Hungarian Natural History Museum, Budapest. The larger brachiopod specimens were photographed by Dávid Dulai.

\section{REFERENCES}

Andri E., Tagliamacco A., Testa M. \& Marchini A. 2005: Le malacofaune fossili del Rio Torsero. Regione Liguria. Catalogo dei Beni Naturali. - Comune di Ceriale, Nuova Editrice Genovese, Genova, 286 pp.

Balson P. S., Mathers S. J. \& Zalasiewicz J. A. 1993: The lithostratigraphy of the Coralline Crag (Pliocene) of Suffolk. - Proceedings of the Geologists Association 104(1): 59-70. http://dx.doi.org/10.1016/S0016-7878(08)80155-1

Baumiller T. K., Bitner M. A. \& Emig C. C. 2006: High frequency of drill holes in brachiopods from the Pliocene of Algeria and its ecological implications. - Lethaia 39: 313-320. http://dx.doi.org/10.1080/00241160600847546

BELl A. 1921: Notes on the Later Tertiary Invertebrata. - Annual Report of the Yorkshire Philosophical Society for 1920: 1-21.

Benigni C. \& Robba E. 1990: A Pliocene Micromorph Brachiopod-Pectinid Community. Atti del Quarto Simposio di Ecologia e Paleoecologia delle Communitá Bentoniche, Sorrento, 1-5 Novembre 1988. - Museo Regionale di Scienze Naturali Torino n. ser. 604: 341-356.

Berggren W. A. \& Couvering J. A. van 1974: The Late Neogene: Biostratigraphy, geochronology and paleoclimatology of the last 15 million years in marine and continental sequences. - Palaeogeography, Palaeoclimatology, Palaeoecology 16: 1-216. https://doi.org/10.1016/0031-0182(74)90032-7

Bertolaso L., Borghi E. \& García Ramos D. 2009: Brachiopodi Neogenici e Pleistocenici dell'Emilia (Parte seconda). - Parva Naturalia 8: 3-42.

Bitner M. A. 1990: Middle Miocene (Badenian) brachiopods from the Roztocze Hills, southeastern Poland. - Acta Geologica Polonica 40: 129-157.

Bitner M. A. \& Dulai A. 2004: Revision of Miocene brachiopods of the Hungarian Natural History Museum, with special regard to the Meznerics collection. - Fragmenta Palaeontologica Hungarica 22: 69-82.

Bitner M. A. \& Martinell J. 2001: Pliocene brachiopods from the Estepona Area (Málaga, South Spain). - Revista Espanola de Paleontología 16(2): 177-185.

Bitner M. A. \& Moissette P. 2003: Pliocene brachiopods from north-western Africa. - Geodiversitas 25(3): 463-479.

Bitner M. A. \& Schneider S. 2009: The Upper Burdigalian (Ottnangian) brachiopod fauna from the northern coast of the Upper Marine Molasse Sea in Bavaria, Southern Germany. Neues Jahrbuch für Geologie und Paläontologie, Abhandlungen 254: 117-133. http://dx.doi.org/10.1127/0077-7749/2009/0006

Bitner M. A., ZÁgoršek K., Halásová E., Hudácková N. \& Jamrich M. 2014: Brachiopods and bryozoans from Sandberg section (Vienna Basin, Central Paratethys) and their significance for environmental interpretation of the Early Sarmatian (= Middle Miocene) Sea. Neues Jahrbuch für Geologie und Paläontologie 273(2): 207-219.

https://doi.org/10.1127/0077-7749/2014/0424

Borghi E. 2001: Osservazioni sui Brachiopodi neogenici e pleistocenici dell'Emilia. - Parva Naturalia 2000-2001: 45-81.

Bosch J. \& Wesselingh F. P. 2006: On the stratigraphic position of the Delden Member (Breda Formation, Overijssel, the Netherlands) with implications for the taxonomy of Pygocardia (Mollusca, Bivalvia). - Cainozoic Research 4: 109-117. 
Bosch M. van den, Cadée M. C. \& Janssen A. W. 1975: Lithostratigraphical and biostratigraphical subdivision of Tertiary deposits (Oligocene-Pliocene) in the Winterswijk-Almelo region (eastern part of the Netherlands). - Scripta Geologica 29: 1-169.

Bosselaers M., Herman J., Hoedemakers K., Lambert O., Mareuet R. \& Wouters K. 2004: Geology and palaeontology of a temporary exposure of the Late Miocene Deurne Sand Member in Antwerpen (N. Belgium). - Geologica Belgica 7(1-2): 27-39.

BRUnton C. H. C. \& CURRY G. B. 1979: British brachiopods. - Synopses of the British Fauna (New Series) 17: 1-64.

BUCKMAN S. S. 1908: Brachiopod nomenclature: the Terebratulae of the Crag. - Annals and Magazine of Natural History (London), ser. 8(1): 444-447. https://doi.org/10.1080/00222930808692430

Calzada S. 1978: Braquiópodos tortonienses de Murcia. - Estudios Geologicos 34: 351-358.

Calzada S. 1997: Miscelánea sobre braquiópodos. - Batalleria 7: 31-34.

Casolari E., Negri A., Picotti V. \& Bertotti G. 2000: Neogene Stratigraphy and Sedimentology of the Gargano Promontory (Southern Italy). - Eclogae Geologicae Helvetiae 93: 7-23.

Chapman F. \& Crespin I. 1923: The Austral Rhynchonellacea of the "Nigricans Series" with a special description of the new genus Tegulorhynchia. - Proceedings of the Royal Society of Victoria 35(2): 170-193.

CHARLESWORTH E. 1837: Observation upon Voluta lamberti, with description of a gigantic species of Terebratula from the Coralline Crag. - Magazine of Natural History and Journal of Zoology, Botany, Mineralogy, Geology and Meteorology, Ser. 2, 1: 90-97.

CHUANG S. H. 1964: The affinity of Lingula dumortieri Nyst with Glottidia. - Journal of Paleontology 38: $155-157$.

Cooper G. A. 1959: Genera of Tertiary and Recent Rhynchonelloid brachiopods. - Smithsonian Miscellaneous Collections 139(5): 1-90.

Cooper G. A. 1983: The Terebratulacea (Brachiopoda), Triassic to Recent. - Smithsonian Contributions to Paleobiology 50: 1-291. https://dx.doi.org/10.5479/si.00810266.50.1

CURRY G. B. 1982: Ecology and population structure of the Recent brachiopod Terebratulina from Scotland. - Palaeontology 25: 227-246.

DALL W. H. 1920: Annotated list of the recent Brachiopoda in the collections of the US National Museum with description of 33 new forms. - Proceedings of the United States National Museum 57(2314): 261-377.

Dautzenberg P. 1909: Description d'une espèce nouvelle de Brachiopode du Pliocène algérien. Journal de Conchyliologie 56: 271-272.

DAutzenberg P. \& Dolfuss G. F. 1896: Du nom à adopter pour la grande Térébratule du Pliocène inférieur d'Anvers. - Annales de la Société Royale Malacologique de Belgique 31: 17-19.

Davidson T. 1852: A Monograph of British Tertiary Brachiopods. Part 1. - The Paleontographical Society, $23 \mathrm{pp}$.

Davidson T. 1870: On Italian Tertiary Brachiopoda. - Geological Magazine 7(8-10): 359-370, 399-408, 460-466. https://doi.org/10.1017/S0016756800209138; https://doi.org/10.1017/S0016756800209497; https://doi.org/10.1017/S0016756800209394

Davidson T. 1874a: A monograph of the British fossil brachiopods, 4(1): supplement to the Recent, Tertiary and Cretaceous species. - Monographs of the Palaeontological Society 27: 1-72.

Davidson T. 1874b: On the Tertiary Brachiopoda of Belgium. - Geological Magazine 11: 150-159. https://doi.org/10.1017/S0016756800169286

Davidson T. 1886-1888: A monograph of Recent Brachiopoda. - Transactions of the Linnean Society of London (2nd ser.) 4: 1-248. https://doi.org/10.1111/j.1096-3642.1886.tb00655.x

Dermitzakis M. 1969: Geological researches of the Neogene deposits of the Hierapetra Province in Crete. - Annales Géologiques des Pays Helléniques 21: 342-484. (in Greek) 
Dollfus G. \& Dautzenberg P. 1901: Nouvelle listes des Pélécypodes et des Brachiopodes Fossiles du Miocène Moyen du Nord-Ouest de la France. - Journal de Conchyliologie 49: 1-52.

DREGER J. 1911: Miocene brachiopoden aus Sardinien. - Verhandlungen der kaiserlich-königlichen Geologischen Reichsanstalt 6: 131-138.

Dulai A. 2010: Early Messinian (Late Miocene) micromorphic brachiopods from Borelli (Italy, Piemonte). - Fragmenta Palaeontologica Hungarica 28: 21-31.

Dular A. 2013: Sporadic Miocene brachiopods in the Naturalis Biodiversity Center (Leiden, the Netherlands): Records from the Mediterranean, the North Sea, and the Atlantic Ocean. Fragmenta Palaeontologica Hungarica 30: 15-51.

Dulai A. 2015: Central Paratethyan Middle Miocene brachiopods from Poland, Hungary and Romania in the Naturalis Biodiversity Center (Leiden, the Netherlands). - Scripta Geologica 149: $185-211$.

Dulai A. \& Mulder H. in prep.: Pliocene brachiopods from Estepona (Spain).

Dulai A. \& STACHACZ M.2011: New Middle Miocene Argyrotheca (Brachiopoda; Megathyrididae) species from the Central Paratethys. - Földtani Közlöny 141(2): 445-468.

Dulai A., Gatt M., Moissette P. \& Janssen A. W. in prep.: Oligocene and Miocene brachiopods of the Maltese Islands: taxonomy, diversity, distribution and paleoecology.

EMIG C. C. 1990: Examples of post-mortality alteration in Recent brachiopod shells and (paleo) ecological consequences. - Marine Biology 104: 233-238. https://doi.org/10.1007/BF01313263

Emig C. C. \& Bitner M. A. 2005: The brachiopod Lingula in the Middle Miocene of the Central Paratethys. - Acta Palaeontologica Polonica 50(1): 181-184.

Emig C. C., Bitner M. A. \& Álvarez F. 2015: Scientific death-knell of databases? Errors induced by database manipulations and its consequences. - Carnets de Geologie 15(16):321-328.

Emig C. C., Bitner M. A. \& CAhuzac B. 2007: First record of Lingula (Brachiopoda) from the Miocene of France, with diagnosis of L. dregeri. - Comptes Rendus Palevol 6: 261-267. http://dx.doi.org/10.1016/j.crpv.2007.02.002

Encinas E. \& Martinell J. 1992: Braquiópodos del Pliocene del Emporda (Catalunya). - III Congreso Geologico de España y VIII Congreso Latinoamericano de Geologia, Salamanca 1992, 1: 501-505.

FisCher P. \& OeHLeRT D. P. 1891: Brachiopodes. Expéditions scientifiques $d u$ "Travailleur" bet $d u$ "Talisman" pendant les années 1880, 1881, 1882, 1883. - Paris, G. Mason, 140 pp.

ForESTi L. 1893: Enumerazione dei Brachiopodi e dei Molluschi Pliocenici dei dintorni di Bologna. - Bollettino della Società Malacologica Italiana 18: 55-72.

Gaetani M. 1986: Brachiopod palaeocommunities from the Plio/Pleistocene of Calabria and Sicily (Italy). - In: Racheboeuf P. R. \& Emig C. C. (eds): Les Brachiopodes fossils et actuels, Biostratigraphie du Paléozoïque 4: 477-483.

Gaetani M. \& SACCÀ D. 1984: Brachiopodi batiali nel Pliocene e Pleistocene di Sicilia e Calabria. - Rivista Italiana di Paleontologia e Stratigrafia 90(3): 407-458.

GAETANi M. \& SACCÀ D. 1985a: Brachiopodici neogenici e pleistocenici della provincia di Messina e della Calabria meridionale. - Geologica Romana 22(1983): 1-43.

Gaetani M. \& Saccà D. 1985b: Il genere Aphelesia (Rhynchonellida, Brachiopoda) nel MioPliocene italiano. - Rivista Italiana di Paleontologia e Stratigrafia 91: 357-378.

García Ramos D. 2004: Braquiópodos pliocenos de Águilas. - Boletín de la Asociación Cultural Paleontológical Murciana 3: 18-39.

García Ramos D. 2005: Notes on some Neogene Brachiopods from south-eastern Spain. Cidaris 21-22: 25-36.

García Ramos D. 2006: Nota sobre Terebratulinae del Terciario de Europa y su relación con los representantes neógenos del sureste español. - Boletín de la Asociación Cultural Paleontológical Murciana 5: 23-83. 
Harper E. M. 2005: Evidence of predation damage in Pliocene Apletosia maxima (Brachiopoda). - Palaeontology 48(1): 197-208. https://doi.org/10.1111/j.1475-4983.2004.00433.x

Janssen A. W. 2012: Systematics and biostratigraphy of holoplanktonic Mollusca from the OligoMiocene of the Maltese Archipelago. - Bollettino del Museo Regionale di Scienze Naturali Torino 28(2): 197-601.

JefFreys J. G. 1878: On the Mollusca procured during the 'Lightning' and 'Porcupine' Expeditions, 1868-70. - Proceedings of the Zoological Society of London 46(1): 393-416. https://doi.org/10.1111/j.1096-3642.1884.tb02813.x

Kocsis L., Dulai A., Bitner M. A., Vennemann T. \& Cooper M. 2012: Geochemical composition of Neogene phosphatic brachiopods: Implications for ancient environmental and marine conditions. - Palaeogeography, Palaeoclimatology, Palaeoecology 326-328: 66-77. http://dx.doi.org/10.1016/j.palaeo.2012.02.004

Koskeridou E. 2007: Pliocene brachiopods from Rhodes Island (Cape Vagia section). - Bulletin of the Geological Society of Greece 40: 121-133.

Lacourt A. W. 1983: De fossiele Brachiopoda van Z. W. Nederland met aantekeningen over Terebratula grandis Blumenbach. - Vita Marina, Ampotigen 1984(nov-dec): 9-50.

LAga P. \& LouwYe S. (2006): Disused Neogene and Quaternary regional stages from Belgium: Bolderian, Houthalenian, Antwerpenian, Diestian, Deurnian, Kasterlian, Kattendijkian, Scaldisian, Poederlian, Merksemian and Flandrian. - Geologica Belgica 9(1-2): 215-224.

Lee D. E. \& Smirnova T. N. 2006: Terebratuloidea. - In: Kaesler R. L. (ed.): Treatise on Invertebrate Paleontology, Part H Brachiopoda Revised, Volume 5: Rhynchonelliformea (part), The Geological Society of America and The University of Kansas, Boulder, Colorado and Lawrence, Kansas, pp. 2054-2081.

Lee D. E. \& Wilson J. B. 1979: Cenozoic and Recent Rhynchonellide Brachiopods of New Zealand: Systematics and Variation in the Genus Notosaria. - Journal of the Royal Society of New Zealand 9(4): 437-463. http://dx.doi.org/10.1080/03036758.1979.10421831

Lee D. E., Brunton C. H. C., Taddei Ruggiero E., Caldara M. \& Simone O. 2001: The Cenozoic brachiopod Terebratula: Its type species, neotype, and other included species. Bulletin of the Natural History Museum (Geology) 57(2): 83-93.

Llompart C. \& Calzada S. 1982: Braquiópodos messinienses de la isla de Menorca. - Boletin de la Real Sociedad Española de Historia Natural 80: 185-206.

Logan A. 1979: The Recent Brachiopoda of the Mediterranean Sea. - Bulletin de l'Institut Océanographique Monaco 72: 1-112.

Logan A. 2007: Geographic distribution of extant articulated brachiopods. - In: SELDEN P. A. (ed.): Treatise on Invertebrate Paleontology. Part H. Brachiopoda Revised. Volume 6, The Geological Society of America and The University of Kansan, Boulder, Colorado and Lawrence, Kansas, pp. 3082-3115.

Logan A., Bianchi C. N., Morri C. \& Zibrowius H. 2004: The present-day Mediterranean brachiopod fauna: diversity, life habits, biogeography and paleobiogeography. - In: Ros J. D., Packard T. T., Gili J. M., Pretus J. L. \& Blasco D. (eds): Biological oceanography at the turn of the Millennium. - Scientia Marina 68(suppl. 1): 163-170.

Manceñidoo M. O., Owen E. F., Dong-Li S. \& Dagys A. S. 2002: Hemithiridoidea. - In: Kaesler R. L. (ed.): Treatise on Invertebrate Paleontology, Part H. Brachiopoda Revised, Volume 4, The Geological Society of America and The University of Kansas, Boulder, Colorado and Lawrence, Kansas, pp. 1326-1369.

MARTinell J. 1982: Borings produced by presumed Pliocene brachiopods from l'Empordà (Catalonia, Spain). - Butlletí de la Institució Catalana d'Història Natural 48 (Secció de Geologia, 3): 91-97. 
Meznerics I. 1944: Die Brachiopoden des ungarischen Tertiärs. - Annales historico-naturales Musei Nationalis Hungarici 36: 10-60.

Moerdij K P. 2007: Indrukken uit het Mioceen. - Afzettingen WTKG 28(4): 78-81.

MoerdijK P. 2016: Een naam voor de Miocene Pliothyrina uit de Westerschelde. - Afzettingen WTKG 37: 106-113.

Monegatti P., Raffi S., Roveri M. \& Taviani M. 2001: A one day trip in the outcrops of the Castell'Arquato Plio-Pleistocene Basin: from the Badlands of Monte Giogo to the Stirone River. - Paleobiogeography \& Paleoecology International Conference, May 31 - June 2, 2001, Piacenza \& Castell'Arquato, Italy, pp. 1-22.

Morgan J. DE 1915: Note sur les Mollusques brachiopods des faluns de la Touraine. - Bulletin de Société Géologique de France, t. 4, 15: 260-273.

Muir-Wood H. 1938: Notes on British Eocene, and Pliocene Terebratulas. - Annals and Magazine of Natural History, Series 11, 2(8): 154-181. http://dx.doi.org/10.1080/03745481.1938.9755448

Müller O. F. 1776: Zoologiae Danicae Prodromus, seu Animalium Daniae et Norvegiae Indigenarum Characteres, Nomina, et Synonyma Imprimis Popularium. - Havniae, $282 \mathrm{pp}$.

Nieulande F. van 2009: Strandfossiel - Terebratula of Pliothyrina, het blijft vragen oproepen. Voluta 15(2): 9-12.

Nyst P.-H. 1843: Description des coquilles et des polypiers fossils des terrains Tertiaries de la Belgique. - Mémoires Couronnés et Mémoires des savants étrangers de l'Académie royale de Bruxelles 17: 1-676.

Nyst P.-H. 1881: Conchyliologie des terrains Tertiaires de Belgique. Première Partie, Terrain Pliocène Scaldisien. - Annales du musée royal d'Histoire naturelle des Belgique, Série Paléontologique 3: $1-263$.

Оттемa J. \& in’t Hout W. 1987: Fossilien uit het 4e havendok bij Kallo, Belgie. - Geologisch Museum Universiteit van Amsterdam: 1-111.

PACAUD J.-M. 2014: Catalogue des types de brachiopodes conservés dans les collections de Paléontologie du Muséum national d'Histoire naturelle de Paris. - Fossiles, hors-série 5: 82-98.

Pajaud D. 1976: Les Brachiopodes du Pliocène 1 de la Sierra de Santa Pola (Sud d'Alicante, Espagne): Terebratula terebratula (Linné, 1758) et Phapsirhynchia sanctapaulensis nov. gen., nov. sp. - Annales de la Société Géologique du Nord 96(2): 99-106.

Pajaud D. 1977: Les brachiopodes du Pliocène 1 de' la région d'Aguilas (Sud d'Almeria, Espagne). - Annales de Paléontologie (Invertébrés) 63(1): 59-75.

Pareyn C., Brebion P., Buge E., Carriol R.-P., Lauriat-Rage A., Le Calvez Y. \& Roman J. 1983: Le gisement pliocène de Cricqueville-en-Bessin (Calvados). Étude géologique et paléontologique. - Bulletin du Muséum national d'histoire naturelle, Paris, 4 e série, 5, section C(4): 367-405.

Pavia G., Berto K C., Ciampo G., Di Donato V., Martire L., Masini F., Pavia M., Santangelo N., TAddei Ruggiero E. \& Zunino M. 2010: Tectono-sedimentary evolution of the Pliocene to Lower Pleistocene succession of the Apricena-Lesina-Poggio Imperiale quarrying district (western Gargano, southern Italy). - Italian Journal of Geosciences 129(1): 132-155. http://dx.doi.org/10.3301/IJG.2009.11

Pedley H. M. 1976: A Palaeoecological Study of the Upper Coralline Limestone, TerebratulaAphelesia Bed (Miocene, Malta) based on bryozoan growth-form studies and brachiopod distributions. - Palaeogeography, Palaeoclimatology, Palaeoecology 20: 209-234. http://dx.doi.org/10.1016/0031-0182(76)90003-1

Piller W. \& Harzhauser M. 2005: The myth of the brackish Sarmatian Sea. - Terra Nova 17(5): 450-455. http://dx.doi.org/10.1111/j.1365-3121.2005.00632.x

Popiel-BARCZyK E. \& BARCZYK W. 1990: Middle Miocene (Badenian) brachiopods from the southern slopes of the Holy Cross Mountains, Central Poland. - Acta Geologica Polonica 40(3-4): 159-181. 
Posselt H. J. 1898: Grønlands Brachiopoder og Bløddyr. - Meddelelser om Grønland 23: 1-9.

RAAD H. 2004a: Kijken naar fossile brachiopoden. - Voluta 10(1): 13-18.

RAAD H. 2004b: Kijken naar fossile brachiopoden, vervolg 1. - Voluta 10(2): 19-22.

RAAD H. 2008: Brachiopoden. - Voluta 14(1): 20-22.

Roy A. van 1980: Pliothyrina, genre Terebratulide (Brachiopode) nouveau du Néogène. - Bulletin de l'Institut royal des Sciences naturelles de Belgique, Sciences de la Terre 52(3): 1-9.

SACCÀ D. 1986: Megerlia echinata (Terebratulida, Brachiopoda) nel Pliocene della Sicilia e della Calabria Meridionale. - Rivista Italiana di Paleontologia e Stratigrafia 92(2): 281-292.

SAcco F. 1902: I Brachiopodi dei terreni terziarii del Piemonte e della Liguria. - Torino, pp. 1-50.

TAdDEI Ruggiero E. 1994: Neogene Salento brachiopod palaeocommunities. - Bollettino della Società Paleontologica Italiana 33: 197-213.

TAdDei Ruggiero E. 1996: Biostratigrafia e paleoecologia delle Calcareniti di Gravina nei dintorni di Cerignola (brachiopodi e foraminiferi). - Memorie della Società Geologica Italiana 51: 197-207.

TAdDEI RUggiero E., Raia P. \& Buono G. 2008: Geometric morphometrics species discrimination within the genus Terebratula from the Late Cenozoic of Italy. - Fossils and Strata 54: 209-217.

Thomsen E. 1990: Application of brachiopods in palaeoceanographic reconstructions; Macandrevia cranium (Müller, 1776) from the Norwegian shelf. - Boreas 19: 25-37. http://dx.doi.org/10.1111/j.1502-3885.1990.tb00418.x

Thomsen E. 2001: Brachiopoda in the Faroe Islands area. - Fróðskaparrit 49: 109-126.

Thomson J. A. 1927: Brachiopod Morphology and Genera (Recent and Tertiary). - N. Z. Board of Science and Art Manual 7: 1-338.

Toscano-Grande A., García-Ramos D., Ruiz-Muñoz F., González-Regalado M. L., Abad M., Civis-Llovera J., González-Delgado J. A., Rico-García A., MartínezChacón M. L., García E. X. \& Pendón-Martín J. G. (2010): Braquiópodos neógenos del suroeste de la depresión del Guadalquivir (sur le España). - Revista Mexicana de Ciencias Geológicas 27(2): 254-263.

VinCEnt E. 1893: Contribution a la paléontologie des terrains Tertiaires de la Belgique. Brachiopodes. - Annals de la Société Royale Malacologique de Belgique 28: 38-64.

Voskuil R. P. A. 2004: De Recente en Tertiaire Brachiopoden van het Nederlandse strand - Een inventarisatie van de literatuur en commentaar op het vermeende voorkomen van Gwynia capsula (Jeffreys, 1859) in Zeeuws-Vlaanderen. - Het Zeepard 64(2): 45-58.

WeSENBER G-LUND E. 1941: Brachiopoda. - Danish Ingolf-Expedition 4(12): 1-17.

Wesselingh F. P. 2003: Een doublet van Terebratula grandis uit de Westerschelde. - Afzettingen WTKG 24(3): 49.

Wesselingh F. P., Peters W. J. M. \& Munsterman D. K. (2013): A brachiopod-dominated seafloor assemblage from the Late Pliocene of the eastern Netherlands. - Netherlands Journal of Geosciences 92(2-3): 171-176. https://doi.org/10.1017/S0016774600000111

Wood S. V. 1872: Supplement to the monograph of the Crag Mollusca or description of shells from the Middle and Upper Tertiaires of the east of England, 3: Univalves and Bivalves. Monographs of the Palaeontological Society London, pp. 99-231.

Zalasiewicz J. A., Mathers S. J., Hughes M. J., Gibbard P. L., Peglar S. M., Harland R., Nicholson R. A., Boulton G. S., Cambridge P. \& Wealthall G. P. 1988: Stratigraphy and Palaeoenvironments of the Red Crag and Norwich Crag Formations Between Aldeburgh and Sizewell, Suffolk, England. - Philosophical Transactions of the Royal Society B 322: 221-272. https://doi.org/10.1098/rstb.1988.0125

ZeZina O. N. 2012: Deep-sea fauna of European seas: An annotated species check-list of benthic invertebrates living deeper than $2000 \mathrm{~m}$ in the seas bordering Europe. Brachiopoda. Invertebrate Zoology 11(1): 83-88. 